\title{
Vying for Relevancy in Stockholm: American Environmental Nongovernmental Organizations and the 1972 UN Conference on the Human Environment
}

\author{
Andrew Brown \\ West Virginia University
}

Follow this and additional works at: https://researchrepository.wvu.edu/etd

\section{Recommended Citation}

Brown, Andrew, "Vying for Relevancy in Stockholm: American Environmental Nongovernmental Organizations and the 1972 UN Conference on the Human Environment" (2014). Graduate Theses, Dissertations, and Problem Reports. 410.

https://researchrepository.wvu.edu/etd/410

This Thesis is protected by copyright and/or related rights. It has been brought to you by the The Research Repository @ WVU with permission from the rights-holder(s). You are free to use this Thesis in any way that is permitted by the copyright and related rights legislation that applies to your use. For other uses you must obtain permission from the rights-holder(s) directly, unless additional rights are indicated by a Creative Commons license in the record and/ or on the work itself. This Thesis has been accepted for inclusion in WVU Graduate Theses, Dissertations, and Problem Reports collection by an authorized administrator of The Research Repository @ WVU. For more information, please contact researchrepository@mail.wvu.edu. 


\title{
Vying for Relevancy in Stockholm: American Environmental Nongovernmental Organizations and the 1972 UN Conference on the Human Environment
}

\author{
Andrew Brown \\ Thesis submitted \\ to the Eberly College of Arts and Sciences \\ at West Virginia University \\ In partial fulfillment of the requirements for the degree of \\ Master of Arts in \\ History
}

James Siekmeier, Ph.D., Chair

Elizabeth Fones-Wolf, Ph.D.

Joseph Hodge, Ph.D.

Department of History

Morgantown, West Virginia

2014

Keywords: Diplomacy, Environment, NGOs, Nixon, Stockholm, Sierra Club, National Audubon Society, Friends of the Earth 


\title{
ABSTRACT \\ Vying for Relevancy in Stockholm: American Environmental Nongovernmental Organizations and the 1972 UN Conference on the Human Environment
}

\begin{abstract}
Andrew Brown
This thesis examines the roles, ideologies, strategies, and behavior of American environmental nongovernmental organizations (ENGOs) during the 1972 United Nations Conference on the Human Environment. This conference was the first major international conference to address environmental issues. The Stockholm Conference was a meeting for delegates representing national governments to dictate the direction of international environmental regulation. The conference focused on the participation of nations but ENGOs found venues through which to participate in the discussion on the human environment. In this thesis, I argue that even though the official conference limited the participation of ENGOs, these groups functioned as informal diplomats in Stockholm. Furthermore, as the U.S. delegation opted to pursue more nationally-focused goals, American ENGOs promoted global-oriented objectives. Thus, the presence of these organizations complicates the narrative of the United States during the conference.

This thesis specifically focuses on three American organizations, the Sierra Club, the National Audubon Society, and the Friends of the Earth International. During the preparatory period of the conference and the conference itself, members of these groups acted as commentators, mediators, discussants, delegates, protestors, and environmental experts. Through their participation, they illuminate much about NGO diplomacy during the 1970s. American ENGOs were unable to influence policy on a major scale during the conference, but their ability to become visible on the international level during the conference established their relevancy as diplomatic agents. ENGO diplomacy, though it grew to full stature in the 1980s, planted its roots in the 1970s, during this conference. This thesis aims to show the impact these organizations had on the conference and how the meeting in Stockholm influenced American ENGOs.
\end{abstract}




\section{Acknowledgements}

When any historian undertakes a project of great magnitude, they inevitably incur many debts and I am no different. I first wish to thank my advisor Dr. James Siekmeier, whose sage advice over the last two years has helped this project take form. He has facilitated my development as a diplomatic historian and scholar and to his confidence in me and my work I owe great thanks. I also wish to thank the other members of my committee, Dr. Elizabeth FonesWolf and Dr. Joseph Hodge, both whose comments helped refine this piece of scholarship and helped provide clarity and direction to this thesis. I am in debt to all of the work they put into helping me write and research. In addition to these faculty members I wish to thank all the faculty members of the West Virginia University History Department, specifically Dr. Krystal Frazier, Dr. Kate Staples, Dr. Gabriel Martinez-Serna, and Dr. Michele Stephens. These faculty members helped me develop as a graduate student throughout my years at West Virginia University and I thank them for their efforts throughout the last two years.

I am further indebted to those who helped with the logistical aspects of research during the last two years. I wish to thank Martha May, Becky Warnke and the rest of the History Department who helped facilitate room reservations and research funding throughout the last year. Mike Thomsen of NYU also deserves thanks as he allowed me a place to stay while I conducted research in New York City. In addition, Armando Torres, a personal friend from Cal State Fullerton helped with some research at the Richard Nixon Library, of which I am immensely grateful. I also wish to thank the archivists at the archives I visited including the Richard Nixon Library, the United Nations Archives, The National Archives at College Park, The National Audubon Society Archives, and the Sierra Club Archives. These archivists pointed me in the right direction for important sources and gave me important information for navigating 
the archival finding aids. Their help cut down the amount of research I needed to do to a manageable level and to them I owe a great debt.

Lastly, I owe a great debt to my family. I wish to thank my siblings for the emotional support they have given me over the last two years. I also am grateful for the efforts made by my parents, $\mathrm{Al}$ and Debbie Brown. My father took almost three thousand photos at the Sierra Club Archives for me and without his efforts this thesis could not be produced. Both my mother and father encouraged and helped me in more ways than can be named and without their faith in me, this piece of scholarship would not exist. It is to them that I dedicate this thesis. 


\section{Table of Contents}

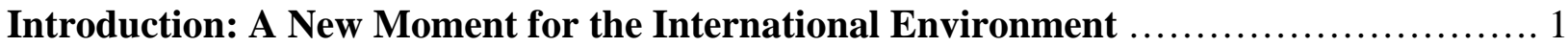

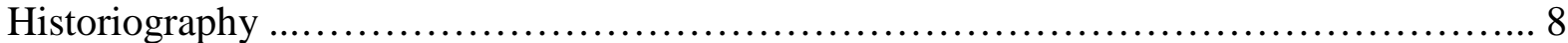

Note on Context and Sources ...................................................... 16

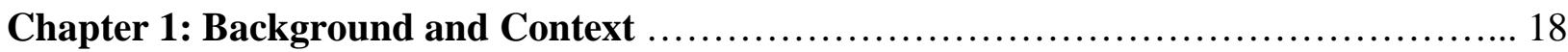

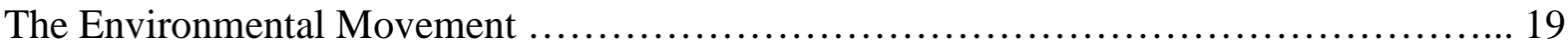

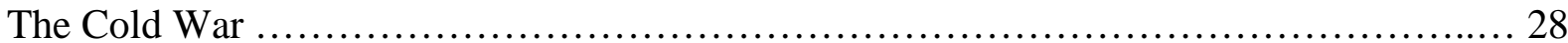

Presidential Politics of the 1960s and 1970s ............................................. 34

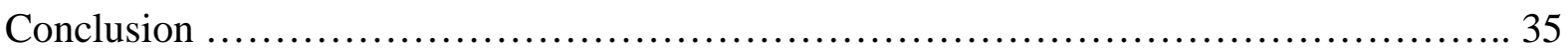

Chapter 2: Fighting for a Successful Conference …................................... 36

The International Scientific Community before Stockholm ................................. 39

State Actors before Stockholm .................................................. 45

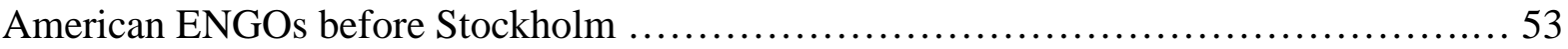

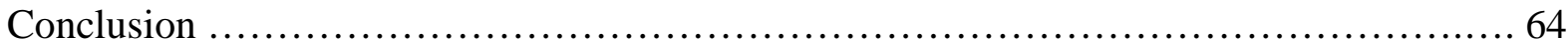

Chapter 3: Fighting for a Declaration, a Voice, and Relevancy ...........................6 66

The United States at the Stockholm Conference ........................................... 69

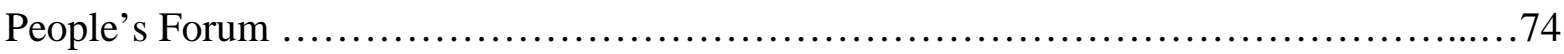

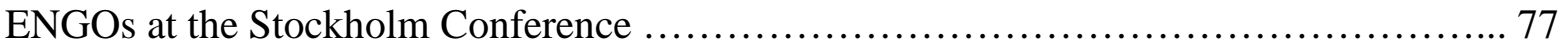

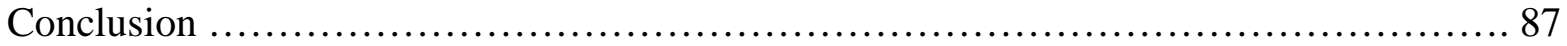

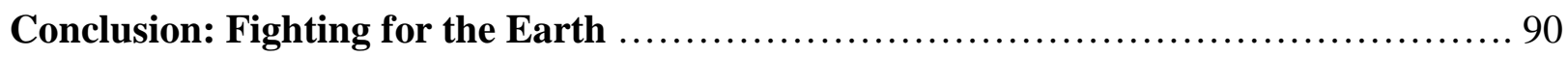

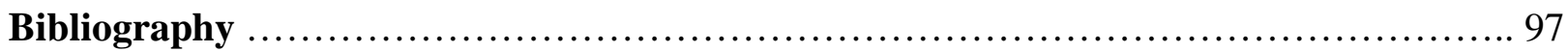




\section{Introduction: \\ A New Moment for the International Environment}

In 1997, legislatures worldwide were deciding whether or not to ratify the 1997 Kyoto Protocol. ${ }^{1}$ The treaty, if ratified, would be the greatest legislative step toward addressing the environmental issue of climate change. The United States, surprisingly, failed to ratify the treaty and took a giant step back from the position of global leader of environmental protection. Declining to ratify the Kyoto Protocol was an ironic decision for the United States, which twenty-five years earlier, vied to become the leader of global environmentalism. The 1972 United Nations Conference on the Human Environment, held in Stockholm, Sweden, was the arena for the United States to assert itself as the leader of the new issue of the human environment.

On July 30, 1968, the United Nations passed Resolution 1346, a document recommending to plan and convene a conference on the human environment. The resolution was a response to the Swedish delegate Sverker Astrom's call for a conference to address environmental issues. The call was not in response to a specific environmental catastrophe or policy, but rather due to the environmental impact of economic development, which is the process of implementing strategic policies to encourage economic growth. ${ }^{2}$ Astrom stated, that "The Swedish government was concerned with the change in the natural surroundings of man brought about, without adequate control, by the use of modern technology advances in industry

\footnotetext{
${ }^{1}$ David Victor, Collapse of the Kyoto Protocol and the Struggle to Slow Global Warming (Princeton: Princeton University Press, 2004), 1.

${ }^{2}$ For important books on the development, consult The History of Development by Gilbert Rist, which looks at development through an international lens, Mandarins of the Future by Nils Gilman, which looks at development and its relationship to modernization theory in Cold War America, and Globalization and its Discontents by Joseph Stiglitz, which focuses on international organizations including the International Monetary Fund and World Bank in the context of Third World economic development.
} 
and agriculture and its impact on man itself." ${ }^{3}$ Development and its impact on the environment were important issues at the Stockholm Conference. Sweden hoped that the conference would give "outlook and direction" to the United Nations and national governments on issues surrounding the human environment. ${ }^{4}$

The resolution established simple goals for the United Nations in constructing the conference. The document stated that UN members were aware of the environmental perils that plagued the world and the continuing efforts by governments and non-state actors to address those problems. In addition, it recommended that "the General Assembly... consider ways and means to further the objectives set out above including, in particular, the desirability of convening a United Nations conference on problems of the human environment." 5 The United Nations saw the conference as a way to further its objectives on economic development, peace, and international cooperation. At this time there was some discussion of economic policy at the international level but the U.N. conference was the first major meeting on this important issue. The United States attempted to use the conference as an attempt to establish itself as the leader of the international environmental movement. The conference sparked a dialogue and in the following years, members of the United Nations saw their ambition to start a conversation manifest into a political reality.

The conversation to address the international environment was rooted in the Cold War narrative of the 1960s and 1970s. The United States sought to establish itself as a leader in the international environment during the 1972 United Nations Conference on the Human Environment. The conference sparked the dialogue on the relation between man's social,

\footnotetext{
${ }^{3}$ Richard Johnston, “UN Health Study Urged by Sweden,” New York Times, May 23, 1968.

${ }^{4}$ Ibid, 1.

5 “United Nations Resolution 1346," United Nations, accessed June 27, 2014, http://www.un.org/ga/search/view_doc.asp?symbol=E/RES/1346(XLV)
} 
political, and economic systems and numerous aspects of the natural environment. National delegations, nongovernmental organizations (NGOs), members of the transnational counterculture movement, and the press all met in Stockholm, Sweden from June 5-16, 1972, each vying for an opportunity to frame the budding debate on the international environment. These groups disagreed on specific policies and approaches to solving the world's environmental catastrophes but all parties agreed that a conversation must commence. State and non-state actors used formal and informal forums to produce constructive and sometimes accusatory dialogue on the global environment. The focus of this thesis is about non-state actors, especially the Americans, in the context of the Stockholm Conference.

The purpose of this thesis is to examine the roles, ideologies, strategies, and impact of a largely neglected group in the Stockholm conference narrative, American environmental NGOs (ENGOs). These environmental organizations, as the subsequent pages show, served as effective informal diplomatic agents and complicate the story of the United States at the conference. Furthermore, their efforts in Stockholm laid the foundation for more involved NGO diplomacy during the next few decades. The chapters outline the narrative of the conference chronologically. The first chapter discusses the American and international environmental movements within the context of the American and international political climates. American and international environmental movements illuminate the issues of importance to delegates and non-state actors in Stockholm and the way the lingering Cold War influenced these issues on an international level.

The various parties that participated in formal and informal domestic and international committees sought to set the agenda for the conference; this is the focus of chapter two. Nonstate actors assembled through UN-sponsored and independent forums to discuss the questions 
posed by the non-state community. These meetings produced policy alternatives, rhetorical backlashes, and a variety of competing visions on the role of American environmental NGOs in world affairs. The American meetings framed the debate at the conference, which is the focus of chapter three. American environmental NGOs assembled at the UN-sponsored Environmental Forum, printed newspaper articles, protested contemporary military and political policies by the United States, and functioned as observers at the official conference. Their multifaceted roles provide an interesting view into the formal and informal venues through which NGO actors function during multilateral negotiations. Their ability to make their positions on the issues known and capacity to organize on an international level altered the foundations of 1970s diplomacy, which scholars have depicted as state-centered. ${ }^{6}$ For the first time American ENGOs made their voices heard although national delegations ultimately dictated policy. The failure by environmental NGOs to influence policy forms the prism through which historians, policy experts, and international relations specialists have viewed NGOs role at the conference and to their scholarship this thesis hopes to add a new interpretation of informal actors in Stockholm.

American ENGOs are the focus of this study and considered primary actors for several reasons. The rise in prominence of environmental organizations in political discourse and the convening of the Stockholm Conference are products of the environmental movement and therefore ENGOs and the conference are important aspects of the modern environmental narrative. Citizens functioned through ENGOs on a local, regional, and national level alongside politicians, lobbyists, and environmentalists. The U.N. Conference on the Human Environment

\footnotetext{
${ }^{6}$ Consult NGO Diplomacy, edited by Michelle Betsill and Elisabeth Correll who primarily refer to NGO diplomacy starting in the 1980s and The History of Development by Gilbert Rist who refers to NGO Diplomacy during the period of structural adjustment in the 1980s. Some historians are beginning to refer to NGOs making a large impact before the 1980s, primarily in the realm of humanitarian affairs. For these views, consult Making the World Safe by Julia Irwin and Diplomacy and Negotiation for Humanitarian NGOs by Larry Roeder and Albert Simard.
} 
was the first opportunity for environmentally-minded citizens, activists, and politicians to assert themselves prominently on the international level. Prior to the conference, national organizations such as the Sierra Club and National Audubon Society had no experience lobbying at the international level because the modern era of international environmental decision-making began with Stockholm. ${ }^{7}$ Their participation complicates our understanding of the United States' role at Stockholm, in that, their globally focused goals diverge from the self-interested goals of the official US delegation. The United States' delegation, as the subsequent pages will show, approached the conference with national interests in mind. While this may not seem surprising, the slogan of the conference "Only One Earth," leads one to believe that this conference served as a new era of international cooperation. Instead, as this thesis later shows, governments, under the guise of international unity, fought to protect their economic and political interests. The United States sought to protect its interests in economic development, foster good relations with the Third World, and project itself as the benevolent leader in global environmentalism.

American ENGOs, as will be discussed later, approached the conference with more globally-oriented goals and advocated for strict environmental regulation that transcended Cold War politics. While American ENGOs did not come to a consensus on how international environmental regulation would unfold, these organizations clearly believed that the environment took primacy over national interests and thus were often at odds with the formal delegation's goals. Analyzing both the formal and informal actors' action during the 1972 conference presents a more holistic view of the birth of international environmentalism in the early 1970s.

\footnotetext{
${ }^{7}$ Michele M. Betsill and Elisabeth Corell, "Introduction to NGO Diplomacy," in NGO Diplomacy: The Influence of Nongovernmental Organizations in International Environmental Negotiations, eds. Michele Betsill and Elisabeth Corell (Cambridge: The MIT Press, 2007), 1.
} 
This thesis focuses on a few prominent American ENGOs, the Sierra Club, the National Audubon Society, and the Friends of the Earth International. These organizations were chosen due to their status at the time of the conference. The Sierra Club and the National Audubon Society were two notable environmental organizations in the United States and the Friends of the Earth International was one of only a few international ENGOs and made a significant impact at the conference. These organizations were based in the United States and while NGOs representing the developed and developing world were present in Stockholm, this thesis focuses on American ENGOs because, as Stephen Hopgood notes, the United States dominated at the conference due to its greater access to environmental research and experience with environmental legislation and politics. ${ }^{8}$ American ENGOs were a part of the dissemination of environmental knowledge and part of the policy process at the national level. Therefore, a conversation on American ENGOs in Stockholm also leads to a discussion on the role of the United States at the conference.

John Muir founded the Sierra Club in the late $19^{\text {th }}$ century. The organization started as a wilderness organization and spent much of its initial efforts on the issue of conservation and forestry. By the 1940s, the Sierra Club battled development projects such as building dams and hydroelectric facilities in the states of Colorado, New Mexico, Utah, and Wyoming. ${ }^{9}$ As time progressed, the organization shifted from regional and local environmental grassroots issues to national legislation. The organization spent much of the 1950s and 1960s lobbying for the Wilderness Act. ${ }^{10}$ In addition to the legislative aspect of the Sierra Club, the organization was

\footnotetext{
${ }^{8}$ Stephen Hopgood, American Foreign Environmental Policy and the Power of the State, (New York: Oxford University Press, 1998), 92-96.

${ }^{9}$ Robert Gottlieb, Forcing the Spring: The Transformation of the American Environmental Movement (Washington DC: Island Press, 1993), 41.

${ }^{10}$ Ibid, 43.
} 
also known for their mountain climbing, skiing, and backpacking trips they organized for members. $^{11}$

The Friends of the Earth organization grew out of the Sierra Club. David Brower, who had been a top official for the Sierra Club, created the Friends of the Earth in 1969. Brower's organization, he envisioned, would "pursue certain issues and strategies that the Sierra Club had not or would not pursue. These included a greater emphasis on international issues... (and) a more direct ideological role through an expanded publishing effort." ${ }^{12}$ Brower wanted to focus less on formulating policy and work on influencing the public and policy makers. His organizational goals help explain the Friends of the Earth's primary contribution to the conference, the creation of the world's first environmental newspaper, Stockholm Conference Eco.

The National Audubon Society, like the Sierra Club, was born out of the progressive movement of the late $19^{\text {th }}$ and early $20^{\text {th }}$ centuries. The organization was primarily interested in the topic of wildlife conservation, namely birds. While the organization primarily served as a traditional club for bird enthusiasts and influencing public opinion, the club made a swift turn in the 1960s with the election of Elvis Stahr Jr. as president. Stahr was interested in transforming the organization into an important player in the policy-making arena. ${ }^{13}$ Stahr was a former Secretary of the Army and presidents of Indiana University and West Virginia and therefore had several connections on the state and national levels. While the National Audubon Society and the Sierra Club were established organizations and the Friends of the Earth was new to the environmental movement, all three organizations faced a new challenge when they prepared for the conference and met in Stockholm to discuss the human environment.

\footnotetext{
${ }^{11}$ Ibid, 41.

${ }^{12}$ Ibid, 144.

${ }^{13} \mathrm{Ibid}, 152$.
} 


\section{Historiography}

Environmental diplomacy is a relatively new field in the historiography of US foreign relations. Kurk Dorsey's book The Dawn of Conservation Diplomacy was one of the first instances in which a diplomatic scholar focused on environmental issues in the context of foreign relations and pioneered the sub discipline of environmental diplomacy. ${ }^{14}$ In 2013 , Dorsey noted on the state of the field of environmental diplomacy that,

Environmental historians have written important books about international subjects, and several historians of science have contributed to what we might broadly consider to be a merger of environmental and diplomatic history, but only a handful of historians of foreign relations have found fruitful research questions in the ways that diplomacy has altered the state of the planet. ${ }^{15}$

Dorsey's work provides an alternative approach to international environmentalism by using diplomacy as the primary focus of investigation. Since Dorsey's work, few books have been produced on the topic of environmental diplomacy. Dorsey notes that J.R. McNeil and Jacob Hamblin ${ }^{16}$ have been prolific authors in the field, but neither scholar comes from a diplomatic background. ${ }^{17}$ Environmental diplomacy attempts to bring together the fields of diplomatic history, environmental history, and the history of science and this thesis seeks to be a contribution to that field.

A more recent contribution to the field of environmental diplomacy is the edited collection titled Environmental Histories of the Cold War edited by J.R. McNeill and Corinna Unger. As a collection, the book shows the complex relationship between important aspects of the Cold War and the environment such as proxy wars, agriculture, Cold War infrastructure such

\footnotetext{
${ }^{14}$ William Cronon, "Forward," in Whales and Nations: Environmental Diplomacy on the High Seas, by Kurk Dorsey (Seattle: University of Washington Press, 2013), ix.

${ }^{15}$ Kurk Dorsey, "Perhaps I was Mistaken: Writing About Environmental Diplomacy Over the Past Decade," Passport 44, no. 1 (April 2013): 37.

${ }^{16}$ For books on environmental diplomacy, specifically on the issues of experts, nuclear weapons, and human ecology, produced by Hamblin refer to Oceanographers and the Cold War and Poison in the Well and for McNeill consult Mosquito Empires and Something New Under the Sun.

${ }^{17}$ Kurk Dorsey, "Perhaps I was Mistaken”, 37.
} 
as dams and highways, military bases, and nuclear weaponry. ${ }^{18}$ The military and economic aspects of the Cold War had significant impacts on the environment. The editors state that while modern environmentalism had many parents and grandparents, it was also a child of the Cold War. ${ }^{19}$ The environmental movement appealed to anti-war protesters in the United States, was a critique of capitalism in the Soviet Union, and was the safest way to criticize the state in China. ${ }^{20}$ Environmentalism was an important part of the Cold War and each topic influenced the other in profound ways as this thesis will later show. While the editors of this collection argue that environmentalism was a part of Détente, ${ }^{21}$ as an issue that could bring East and West together, the conference in Stockholm rather illuminated the political and economic polarities of the Cold War.

This thesis further converges with the historiographies of international political history and environmental history. In order to understand the actions, ideologies, and strategies of the various diplomatic agents, it is important to contextualize the conference with how it fits in within environmental, international, and political narratives. The Stockholm Conference, which convened in 1972, occurred during an important moment of international political history. Various groups challenged the East-West power politics of the Cold War. During the 1960s, the Third World began to come together through movements and institutions such as the Nonaligned Movement. These countries made a commitment to an independent foreign policy, peaceful coexistence, to support national liberation movements, and to avoid Cold War alliances. ${ }^{22}$ China, on the other hand, was experiencing a time of transformation at the dawn of the Stockholm

\footnotetext{
${ }^{18}$ J.R. McNeill and Corinna Unger, "The Big Picture," in Environmental Histories of the Cold War, eds. J.R. McNeill and Corinna Unger (New York: Cambridge University Press, 2010), 5.

${ }^{19}$ Ibid, 11.

${ }^{20}$ Ibid, 12.

21 Ibid, 13.

${ }^{22}$ Mark Lawrence, "The Rise and Fall of Nonalignment," in The Cold War in the Third World, ed. Robert McMahon (New York: Oxford University Press, 2013), 144.
} 
Conference. In 1972, the Sino-Soviet Split and Sino-American rapprochement influenced Chinese foreign policy, as China started to normalize relations with the United States, and China was on the verge of sharing its Three World Thesis. ${ }^{23}$ Two years after the conference, Mao Zedong introduced his Three World Thesis and stated that China was part of the Third World. ${ }^{24}$ Global political transformations, such as the Nonaligned Movement and the geopolitical evolution of China, significantly influenced the Stockholm deliberations as the developing world resisted many of the environmental proposals of the developed world and China sought to become the leader of the nonaligned states. Therefore, as this thesis will later discuss, the geographical and political divisions American ENGOs encountered at the conference were an effect of political maneuvers in the 1960s and 1970s.

While China and the Third World aimed to challenge the power of the US and USSR, international groups also engaged with important aspects of the post-World War II era such as environmentalism and economic development. Authors, experts, and organizations challenged the concept of development and undertook international environmental programs before the Stockholm Conference. The discourse surrounding economic development was changed when international economists such as Hans Singer, Barbara Ward, Raul Prebisch, Gunnar Myrdal, Jan Tinbergen, and others began combining social reform with development, the idea of "growth plus change." ${ }^{, 25}$ Books such as the Limits of the Earth by Fairfield Osborne and The Limits to Growth by Donella Meadows warned of a catastrophic future due to unrestricted population growth and mismanagement of natural resources.

\footnotetext{
${ }^{23}$ Chen Jian, "China, the Third World, and the Cold War," in The Cold War and the Third World, ed. Robert McMahon (New York: Oxford University Press, 2013), 96.

${ }^{24}$ Ibid, 85.

${ }^{25}$ Iris Borowy, Defining Sustainable Development for our Common Future: A History of the World Commission on Environment and Development (New York: Routledge, 2013), 20.
} 
Organizations such as the United Nations Educational, Scientific, and Cultural Organization (UNESCO) and the International Biological Program (IBP), alongside the economists named earlier, focused on efforts of the international environment. These organizations instituted efforts to address environmental issues on an international scale. The Man and the Biosphere program (MBP), a program of UNESCO created in 1971, "supported the designation of areas where economic activities should serve environmental protection." ${ }^{26}$ In other words, the areas governed by the MBP served as "demonstrations for cooperation in building harmonious relationships between human activities and the conservation of ecosystems and biological diversity." ${ }^{27}$ The IBP, also addressed issues of the human environment, intertwined with the issue of development.

"The International Biological Program (IBP) grew out of mounting scientific concern throughout the world for the major problems confronting mankind... rapidly increasing population, food shortages and environmental destruction. As early as 1959, scientists began discussing the possibilities of organizing an international program dealing with increasing food supplies and keeping the earth a fit place to live. ${ }^{28}$

In the early 1970 s, national organizations began implementing international programs to contribute to the advances made by international organizations in the 1950s and 1960s. National NGOs sought to contribute in an arena where they had previously been neglected. Before the Stockholm Conference, environmental organizations only played a limited role in the United Nations. ${ }^{29}$ Organizations such as the Sierra Club and the National Audubon Society used the burgeoning field of international environmentalism to transform their organizations in fundamental ways. By the time of the Stockholm Conference, several groups and experts were

\footnotetext{
${ }^{26}$ Ibid, 27.

${ }^{27}$ United States Man and the Biosphere Program, Biosphere Reserves in Action: Case Studies of American Experience (Washington DC: Department of State, 1995), v.

${ }^{28}$ Man's Survival in a Changing World: United States Participation in the International Biological Program, Box B-340, Folder 6, National Audubon Society Archives, New York Public Library, New York, NY.

${ }^{29}$ Ken Conca, "NGOs, the UN, and Global Governance," in Environmental Organizations and the UN System, eds. Thomas Weiss and Leon Gordenker (Boulder: Lynne Rienner Publishers, 1996), 104.
} 
discussing the looming doom and advocating for a new, eco-friendly version of development or a curb in development activities.

The type of environmentalism exhibited by these American ENGOs at the Stockholm Conference is very specific. In the United States, environmentalists branded the environmental movement as a grassroots, democratic process. Social activists in early $20^{\text {th }}$ century Chicago utilized the community to address environmental issues in the workplace and human settlements, while members of the counterculture latched onto the modern environmental movement as a medium for social change. ${ }^{30}$ This is a unique kind of environmentalism but the historiography of international environmentalism, specifically within the British Empire, shows a different way in which environmentalism exhibited in the world.

Environmentalism within the British Empire manifested through the process of colonization. Richard Grove, a notable British historian on environmental history, argued that the origins of Western environmentalism go far back in time, to the days of European colonization. ${ }^{31}$ Environmentalism was born out of the process of imperialism and was concocted in the tropical colonies. Two ideas greatly influenced the idea of Western environmentalism, the garden and the island. The idea of the garden originated from the colonizer's contact with the natural beauty of the tropics. It represented man's redemption and returning to the paradise of Eden. The island was an allegory for the entire earth. The tropics served as models of the world and exhibited, on a micro-scale, man's impact on his natural environment. ${ }^{32}$ These ideas together served as the impetus for the Western version of environmentalism.

\footnotetext{
${ }^{30}$ Robert Gottlieb, Forcing the Spring: The Transformation of the American Environmental Movement, 63-
} 98.

${ }^{31}$ Richard Groves, Green Imperialism: Colonial Expansion, Tropical Island Edens and the Origins of Environmentalism, 1600-1860 (Cambridge: Cambridge University Press, 1996), 1.

${ }^{32}$ Ibid, 13. 
While the ideological currents in the colonial form of environmentalism were similar to that of this social movement in the United States, the implementation of environmental regulation differs in fundamental ways. The environmental movement in the United States formed from the ground-up but the government and scientists in the British colonial context governed the same process. A group of highly influential scientists and politicians developed the three-part ecology of the British Empire, nature, knowledge, and society. ${ }^{33}$ Therefore, environmentalism was not a democratic but rather an autocratic process. Scientists argued that instead of leaving natural areas, such as the forest, autonomous, it should be managed and improved by science. ${ }^{34}$ The British Empire managed their colonial lands and forced environmental regulation on the native population. People of the colonies viewed environmentalism as a police action and abusive. ${ }^{35}$

Environmentalism, in the context of the British Empire, illuminates much about the Stockholm Conference. First, the importance of experts, as scientists appeared in Stockholm as advisors and members of international organizations such as Dai Dong and Founex. Secondly, the Third World's contact with environmentalism started in the context of colonization. To the Third World, it was an autocratic process imposed on their society rather than a grassroots movement to protect their community. Lastly, that environmentalism held antiquated origins. The delegates in Stockholm, official or informal, approached an issue the world contemplated for several centuries. The issue of environmental protection was an important topic in the context of the Cold War and there was no easy answer to the complex problem debated in Stockholm.

\footnotetext{
${ }^{33}$ Peder Anker, Imperial Ecology: Environmental Order in the British Empire, 1895-1945 (Cambridge: Harvard University Press, 2002), 2.

${ }^{34}$ Gregory Barton, Empire Forestry and the Origins of Environmentalism (Cambridge: Cambridge University Press, 2002), 37.

${ }^{35}$ Ibid, 6-165.
} 
The literature on the conference emphasizes the Stockholm meeting's importance to global environmentalism but rarely engages with the conference on its own terms. Most historians, environmental policy experts, and political scientists contend that this conference was the beginning of the larger international environmental movement and argue that it provided the framework for subsequent environmental negotiations. Yet, despite its importance, scholars primarily discuss the conference as historical context for more recent meetings rather than as the principal topic of study. The absence of detailed research about the conference calls for historians to study this important event in history on its own terms.

Only a few works exist that focus primarily on the conference. Stephen Hopgood's book entitled American Foreign Environmental Policy and the Power of the State is the most comprehensive study of the conference. Hopgood, a political scientist, believed that America's role at the conference can be explained through its power in world affairs. He argued that America's prominence at the conference was rooted in its experience in environmental affairs and economic ability to carry out environmental initiatives. ${ }^{36}$ Furthermore, he maintains that the United States' capacity for environmental research and implementation of new environmental technology allowed for America to assume a leadership position on an issue that was relatively new on the international stage. ${ }^{37}$ While Hopgood's analysis clarifies how the United States became the major actor at the conference, he fails to conclude what shaped their goals and what motivated the delegation to pursue a leadership position in the conference. America's approach to the conference in Stockholm, as this thesis shows, was influenced by self-interested goals.

John Cohrssen, a prolific author on the environment, adds to the field of environmental diplomacy. He argues that the United States has deferred environmental sovereignty to

\footnotetext{
${ }^{36}$ Stephen Hopgood, American Foreign Environmental Policy and the Power of the State, 92.

${ }^{37}$ Ibid, 96.
} 
international organizations. ${ }^{38}$ In essence, the United States has allowed the United Nations to manage environmental diplomacy rather than becoming an issue part of bilateral agreements between nations. The issue of sovereignty is important in regards to the topic of international environmentalism. The United States rarely elects to sacrifice it, developing countries feared losing it, and ENGOs sought to strengthen international standards rather than focus on each nation's right to self-determination. International forums tend to provide justification for the programs promoted by the United States. State actors, as much of this thesis shows, acted with self-interest and economic interests at heart. ENGOs acted with more globally-oriented goals.

While the United States elected to vie for sovereignty on the topic of environmental issues, the conference itself fits within the issue of European liberal internationalism. After the Bretton Woods Conference, European nations advocated for international institutions to play a larger role in world affairs. ${ }^{39}$ During the Cold War, these institutions took the form of the International Monetary Fund and World Bank and after the Cold War, institutions such as the World Trade Organization and European Union emerged. ${ }^{40}$ The Stockholm Conference, as it acted within a United Nations context, fit within this new era of international negotiations. While the conference occurred within this context, governments still approached the conference with their own agendas and priorities concerning the human environment.

The most comprehensive study on NGOs at the conference is Wade Rowland's book Plot to Save the World. In his study, he devotes a chapter to non-state actors at the Stockholm Conference. Rowland dismisses much of the efforts of non-state actors in Stockholm and with

\footnotetext{
${ }^{38}$ John Cohrssen, "US International Interests, Sustainable Development, and the Precautionary Principle," in The Greening of US Foreign Policy, eds. Terry L. Anderson and Henry I. Miller (Stanford: Hoover Institution Press, 2000), 115.

${ }^{39}$ Beate Jahn, Liberal Internationalism: Theory, History, Practice (New York: Palgrave MacMillan, 2013), 80.

${ }^{40}$ Ibid, 80.
} 
the exception of the international group Dai Dong concludes that, "Other activities of the group (NGOs) were, however, little more helpful that those of the Life Forum."41 The Environmental Forum, which was the gathering of NGOs, and the Life Forum, ${ }^{42}$ the gathering of international activist youth, garners little attention from Rowland as either group had little impact on policy but as this study shows, the informal arena of diplomacy illuminates the deep-seeded impact of these actors at the conference. Though he dismisses the impression ENGOs made on the conference and environmental diplomacy more broadly, he does name the environmental organizations the "official conscience for the UN delegates." 43 Because ENGOs did not have to answer to national interests, they formed more ideological agendas and their presence at the conference displayed their vision for a green future.

\section{Note on Context and Sources}

The pages that follow chronicle the actions, ideologies, and impacts of a group marginalized in the historiography but their deeds cannot be understood on their own. While the environmental NGOs may have been the official conscience of Stockholm, they were not the only voice. This research places the narrative of these informal actors and the conference within the parallel discourse on state actors and the wider world in the 1960s and 1970s. By using this strategy to relay the story of these organizations, I hope to show their importance and the diversity they brought to this new moment in international environmentalism. To do this, I have drawn from extensive archival and published primary sources, including the papers from the

\footnotetext{
${ }^{41}$ Wade Rowland, The Plot to Save the World: The Life and Times of the Stockholm Conference on the Human Environment (Toronto: Clarke Irwin, 1973), 125.

${ }^{42}$ The Stockholm Conference had three major meetings occurring simultaneously. The official conference consisted of governmental delegations and produced the official declaration on the human environment. The Environmental Forum was the meeting of NGOs from around the world and was made up of workshops, lectures, and film viewings. The Life Forum, also known as the People's Forum or Folklet's Forum, was a meeting of primarily leftist youth who held meetings called POW WOWs and spent much of their time protesting imperial powers present at the conference.

${ }^{43}$ Wade Rowland, The Plot to Save the World, 121.
} 
Sierra Club Archives, the National Audubon Society Archives, the Richard Nixon Presidential Library, the National Archives at College Park, and the United Nations Archives. Among my secondary sources, I draw from the literature created by historians, environmentalists, public policy experts, political scientists, and public officials. By using these diversified archival and secondary sources, I wish to paint a more holistic picture of the conference in Stockholm; what follows is the manifestation of that mission. The American ENGOs discussed throughout this thesis accumulated a modest amount of relevancy during the Stockholm Conference but NGO diplomacy, as scholar Sangeeta Kamat shows, became a "global phenomenon" in the 1980s. ${ }^{44}$ For American ENGOs such as the Sierra Club, the National Audubon Society, and the Friends of the Earth, their relevancy in international took root during the Stockholm Conference.

${ }^{44}$ Sangeeta Kamat, "The NGO Phenomenon and Political Culture in the Third World," Development 46, no. 1 (2003): 89. 


\section{Chapter 1: \\ Background and Context}

On March 27, 1972, about two months before the conference, the Department of State sent a letter to Raymond Sherwin, the president of the Sierra Club, about the issue of East Germany's admittance to the conference. The letter began, "We share your concern over the threatened boycott of the 1972 Conference on the Human Environment by the Soviet Union and we trust the USSR will ultimately decide to attend." ${ }^{45}$ The State Department's letter was a response to the Sierra Club's recommendation of East Germany's admittance to the World Health Organization, which would make them eligible to participate in the 1972 conference. If East Germany was barred from the conference, the USSR threatened to boycott. The Sierra Club recognized that a boycott of the conference by the Soviet bloc would severely compromise its results and conflicted with the conference's theme of global unity. While the issue of East Germany's exclusion at the conference is described in detail in the next chapter, this dispute is one instance of how political, social, and economic processes ultimately shaped the conference.

Contemporary events shaped the conference and the actors within it as well. The 1972 United Nations Conference on the Human Environment, and especially the role of American Environmental NGOs in the conference, was shaped by several American domestic and international developments. To explore these developments, this chapter will focus on three factors that influenced events in Stockholm, including the emergence of the modern environmental movement, the Cold War, and the 1960s and 1970s political climate.

\footnotetext{
${ }^{45}$ Letter, Office of the Secretary of State to the Sierra Club, March 27, 1972, Box 130, Folder 14, Michael McCloskey Papers, Bancroft Library, Berkeley, CA.
} 


\section{The Environmental Movement}

\section{The American Environmental Movement}

The American environmental movement has a long history. Since the nation's inception, there have been environmentally focused individuals, but an organized movement first emerged in the late nineteenth century but became increasingly popular in the 1960s. Kirk Dorsey argues that modern environmentalists are following in the footsteps of Progressive Era conservationists. ${ }^{46}$ During that time, the United States joined in wildlife protection treaties with Canada. Conservationists argued that fish, seals, and birds did not adhere to national boundaries, so environmentalists started looking at the environment through transnational lenses. The government acknowledged that conservation was not simply a domestic issue. There was a newfound awareness that nations needed to cooperate with each other in order to promote conservation. $^{47}$

Conservation issues mobilized environmentalists in the late nineteenth and early twentieth centuries, but one must question, what spurred the environmentalist's activism? According to Lester Milbrath, a political scientist:

"The plentiful supply of cheap land in the new world led many immigrant settlers to exploit land ruthlessly, with little concern for future generations. Land was treated as a commodity, enabling some people to get rich quickly; this also led to widespread speculation in land ownership. The exploitive mentality toward land was carried to such an extreme that it created a reaction that took the form of the Conservation Movement." 48

The beginnings of the Conservation movement is closely linked with the push west by eighteenth and nineteenth century Americans. Early settlers saw the space as virgin land and this

\footnotetext{
${ }^{46}$ Kirk Dorsey, The Dawn of Conservation Diplomacy: US-Canadian Wildlife Treaties in the Progressive Era (Seattle: University of Washington Press, 1998), 3.

${ }^{47}$ Ibid, 4.

${ }^{48}$ Lester Milbrath, Environmentalists: Vanguard for a New Society (Albany: State University of New York Press, 1984), 67-68.
} 
glamorized view convinced many Americans to preserve what they saw as the land's natural integrity. Americans moving west were able to buy land cheap and the abundance of "open land"49 decreased its intrinsic value to settlers and homesteaders. The fear of mass degradation of the land drove Progressive Era environmentalists to act.

The interests of American environmentalists evolved over time and embodied several issues. Progressive era conservationists sought to protect natural resources and early in the movement, this meant the forests. ${ }^{50}$ Conservationists sought to protect unspoiled natural space through federal law, such as establishing state and federal park programs. Yellowstone National Park, established in 1872 by Ulysses S. Grant, was the first national park in the United States. Teddy Roosevelt expanded the number of parks in the country and took a picture with John Muir when he visited Yosemite. Woodrow Wilson signed the National Park Service into law in 1916, formalizing the United States' commitment to cultural land conservation. It is important to note though that their devotion to land conservation did not reduce their belief in economic and industrial development. Conservationists accepted the existing "economic-social-political arrangements of society... Most of them saw no conflict between conservation and economic growth" ${ }^{\circ 1}$ This stance mirrors the nineteenth century vision of the West, a pristine natural wonderland with the possibility of economic and industrial prosperity. After decades of industrial development, "Human degradation of the environment advanced to what many began

49 I use "open land" because of the ideas conservationists and the public held about nature and the West. According to Gerald Nash, conservationists saw nature and the mythical West as a vision of perfection and a remnant of the pristine agrarian past. Conservation became an avenue to protect the romanticized West. The idea of "open land" also reflects the contemporary racist idea that the land was not currently settled until cultivated by European settlers. Also, consult the book 1491 by Charles Mann who dispels this notion of "virgin land" and argues that Native Americans had a much greater impact on their environment than previously thought.

${ }^{50}$ Gifford Pinchot, "The Fight for Conservation" in American Environmentalism: The Formative Period, 1860-1915, edited by Donald Worster, (New York: John Wiley \& Sons, 1973), 85.

${ }^{51}$ Lester Milbrath, Environmentalists: Vanguard for a New Society, 68. 
to believe was an alarming level; the movement began transforming from a conservation movement to an environmental protection movement.",52

Progressive Era environmentalists generated ideas about the environment, which appeared throughout the twentieth century in the United States. After the Dust Bowl, scientists focused on the issue of soil conservation. The U.S. government created the United States Soil Conservation Service in 1932 and Hugh Bennett served as its Chief. Bennett worked to improve soil conditions at the home but also brought his expertise abroad including making trips to South Africa in the mid-1940s. ${ }^{53}$ Efforts to protect the environment lasted throughout the twentieth century but the modern environmental movement began in 1962. The ideology that propelled environmentalism was self-preservation. It acknowledged that human survival on the planet was dependent on the status of its environment. As Maurice Strong, the general secretary of the conference stated:

The insight that humans inflict damage on themselves by damaging nature has become a basic premise of modern environmentalism as it emerged as a major and influential movement during the second half of the twentieth century... Impacts [on the environment] were dramatically pointed out by Rachel Carson in her influential book, Silent Spring (1962). ${ }^{54}$

Rachel Carson's book on pesticide use, particularly DDT, argued that pesticides were hurting birds, plants, other animals, and humans. Self-preservation, an idea prominent in Silent Spring, prompted a mass movement by individuals all over the nation to protest on behalf of the environment.

Self-preservation is consistent with the ideology employed by progressive era conservationists. "They [Conservationists] skillfully combined the romantic view [of nature]

${ }^{52}$ Ibid, 69.

${ }^{53}$ Belinda Dodson, “A Soil Conservation Safari: Hugh Bennett's 1944 Visit to South Africa," Environment and History 11, no. 1 (2005): 36.

${ }^{54}$ Maurice Strong, "Global Sustainable Development," in Globalization, Globalism, Environments, and Environmentalism, eds. Steven Vertovec and Darrell Posey (New York: Oxford University Press, 2004), 105. 
with Christian conceptions of American prairies and forests, sensing that the wilderness was inextricably bound up with national character and destiny." 55 Whether it was preservation of the nation or preservation of the human species, popular environmentalism sought to safeguard the aspect of the environment that connected with humankind. American ENGOs used the idea of self-preservation to influence the populace and delegates at the Stockholm Conference but also held to a different ideology that influenced their policy proposals.

John Muir's approach to the environment influenced activists in the 1960s and early 1970s. Muir, "saw man immersed in nature rather than lord over nature." 56 Through this approach, modern environmentalists saw an inherent value in nature separate from man's connection with it. This difference between conservation and preservation is an important aspect of environmentalism. The American conservation movement sought to better manage the abundance of resources in the United States. ${ }^{57}$ Preservation, on the other hand, sought to protect the environment from harm. The divergence of these ideas occurs for an important reason. The battle for conservationism took place in national parks and forest lands whereas environmentalism and preservationism occurred in industrial, urban, and agricultural areas. ${ }^{58}$

The early American environmental movement was split into three different groups. First were those interested in public health concerns. ${ }^{59}$ Silent Spring resonated with these activists. They participated in campaigns against DDT, Agent Orange, and herbicides. The second group

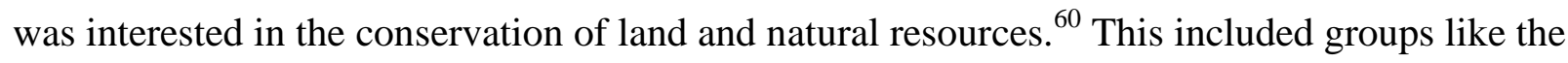

\footnotetext{
${ }^{55}$ Gerald Nash, “The West as Utopia and Myth,” Montana: The Magazine of Western History 41, no. 1 (1991): 71 .

${ }^{56}$ Lester Milbrath, Environmentalists: Vanguard for a New Society, 68.

${ }^{57}$ Benjamin Heber Johnson, "Conservation, Subsistence, and Class at the Birth of Superior National Forest," in American Environmental History, ed. Louis Warren (Malden: Blackwell Publishing, 2003 ), 180.

${ }^{58}$ Robert Gottlieb, "Reconstructing Environmentalism: Complex Movements: Diverse Roots," in American Environmental History, ed. Louis Warren (Malden: Blackwell Publishing, 2003), 245.

${ }^{59}$ Gary Haq and Alistair Paul, Environmentalism Since 1945 (New York: Routledge Press, 2012 ), 7.

${ }^{60}$ Ibid, 8 .
} 
Sierra Club, which supported legislation protecting wildlife, water, and air. The third group appeared in the 1960s and was less interested in the issue of the environment than fighting the establishment. $^{61}$ This was a younger group of activists who used the issue of the environment as an outlet for their rebellion and rage against the government.

At the end of the 1960s and into the 1970s, the public showed its concern about the environment through the growth of ENGOs. The number of organizations and the size of each organization grew tremendously throughout this period. Before 1960, on average three new environmental organizations appeared per year in America, after 1960, each year averaged eighteen new organizations. ${ }^{62}$ The growth of environmental organizations in the United States made environmentalism an important political force.

The momentum of the American environmental movement led to important federal institutional changes and legislative initiatives in the late 1960s and early 1970s. These changes were also in response to contemporary environmental disasters that caught the attention of the public. In 1969, two environmental disasters prompted a backlash from the public. The Santa Barbara oil spill and the fire on the Cuyahoga River created public pressure on the Nixon administration to develop methods to protect the environment, which responded by establishing the Council on Environmental Quality (CEQ) in 1969 and the Environmental Protection Agency (EPA) in $1970 .^{63}$ Preceding the Stockholm Conference, Nixon initiated Earth Day on April 20, 1970, one of the many environmental enterprises created as a testament to Nixon's pledge to the environment. National delegates voted during the conference to name June 5 as World Environment Day. Through this vote, national delegations decided to promote internationally a

\footnotetext{
${ }^{61}$ Ibid, 7.

${ }^{62}$ J. Brooks Flippen, "Richard Nixon and the Triumph of Environmentalism," in American Environmental History, ed. Louis Warren (Oxford, UK: Blackwell Publishing, 2003), 277.

${ }^{63}$ John Cohrssen, "US International Interests, Sustainable Development, and the Precautionary Principle" in The Greening of U.S. Foreign Policy, 116.
} 
sentiment that was already growing in the United States. It is important to note though that the American environmental movement was only one cog in the wheel of environmentalism.

Developments on the international stage also influenced the conference and the NGOs that acted in it.

\section{Environmental Movements Abroad}

The United States was a major player in the growth of the environmental movement, but it was far from the only participant in environmental affairs. As John McCormick, the notable political scientist, stated, "The movement did not begin in one country and then spread to another; it emerged in different places at different times." ${ }^{64}$ The modern environmental movement took different forms in different countries. The forms these movements took influenced the philosophical approaches nations and non-state actors formulated during the build-up to the Stockholm conference. Therefore, to understand the ideologies of the various actors in Stockholm in 1972, it is important to contextualize their efforts by discussing the environmental movements appearing around the world. As discussed earlier, environmentalism throughout the last few hundred years was both an autocratic and democratic process. Environmentalism served as a function in imperial processes and grassroots efforts. American ENGOs saw themselves as part of a grassroots democratic movement, therefore the next few pages will primarily focus on grassroots environmental movements during the twentieth century. ${ }^{65}$

Why were these environmental movements appearing in several parts of the developed world? As J.R. McNeil notes, “The twentieth century was unusual for the intensity of change and

\footnotetext{
${ }^{64}$ John McCormick, Reclaiming Paradise: The Global Environmental Movement (Bloomington: Indiana University Press, 1991), 1.

${ }^{65}$ For more information on American ENGOs and the American environmental movement, reference Forcing the Spring by Robert Gottlieb.
} 
the centrality of human effort in provoking it." 66 The evolution of technology, the budding role of modernization projects ${ }^{67}$, the growing destructive capacity of weaponry, and the mounting attention given to economic growth increased man's ability to manipulate and degrade his environment. The rising capacity for man to influence his natural surroundings spawned ecological disasters that captured the attention of the public but it was clear that the disasters had to form a recognizable danger in order to merit a response from the citizenry:

Domestic politics in open societies proved mildly more responsive to environmental problems that annoyed citizens than did more authoritarian societies, especially after 1970 , but there were clear limits to the ecological prudence that citizens wanted. Regardless of political system, policy makers at all levels from local to international responded more readily to clear and present dangers (and opportunities) than to the more subtle and gradual worries about the environment. More jobs, higher tax revenues, and stronger militaries all appealed, with an immediate lure that cleaner air or diversified ecosystems could not match. ${ }^{68}$

Contemporary troubles, rather than apocalyptic jargon, spurred citizens to mobilize for environmental protection. Environmental disasters occurred across the globe and as we shall see in the cases of Britain, France, and Czechoslovakia, environmentalism brought forth various methods to enacting environmental regulation and generated environmental philosophies adopted by ENGOs during the 1972 Stockholm conference.

Britain has a long-standing history with environmentalism. Their attentiveness to environmental dangers made them a pioneer of environmental regulation in Europe. Their relationship with environmental protection goes beyond the era of progressive conservationism but dates back to the thirteenth century.

${ }^{66}$ J.R. McNeill, Something New Under the Sun: An Environmental History of the Twentieth Century World, (New York: W.W. Norton \& Company, 2001), XXII.

${ }^{67}$ For the United States, modernization projects were designed to bring a country, in the Cold War context the Third World, into political, economic, and cultural modernity. To the U.S., key aspects of modernity were democracy, capitalism, and liberalism. For more information on the subject, consult Mandarins of the Future by Nils Gilman.

${ }^{68}$ J.R. McNeill, Something New Under the Sun, 355. 
Britain has an impressive record in recognizing and responding to environmental degradation. In 1273 it passed what may have been the world's first piece of antipollution legislation (a decree prohibiting the burning of sea coal). In 1863 it set up the first pollution control agency (the Alkali Inspectorate)... In 1956 it was the first major industrialized nation to pass a clean air act. In 1970 it created the world's first cabinet-level "environment department.",69

Domestically, Britain's road to environmental protection primarily passed through the walls of Parliament. In addition, as stated in the introduction, environmentalism in the imperial context was managed by politicians and scientists. To compliment these efforts, citizens joined ENGOs and advocated for natural preservation but Britain's great strides came through the government's adoption of environmental standards and environment-affiliated governmental agencies. Other nations, the United States in particular, conformed to this method and governments asserted themselves as important agents in the fight against looming environmental perils. Many developed nations at the Stockholm conference, including the United States, thought nationally administered environmental programs was the most efficient and prudent method to implement environmental regulation around the world. This approach, originally, did not apply to all nations though, as France's move toward environmentalism bred from anti-governmental attitudes.

In France, negative opinions of the state gave rise to environmentally focused movements. Strict pro-environment philosophies fit within the political climate in France in the 1960s. French protesters sought new frontiers in which to clash with the government. These activists saw the state as the primary instigator of environmental degradation and started to fight the centralized government on that front. In this case, environmentalism fit in with the popular anti-statist and anti-consumer attitudes of the time. ${ }^{70}$ Ironically, the quest for strict environmental regulation led to a stronger centralized government and the state became a key component into

\footnotetext{
${ }^{69}$ John McCormick, Reclaiming Paradise, 127.

${ }^{70}$ Michael Bess, "Greening the Mainstream: Paradoxes of Anti-Statism and Anti-Consumerism in the French Environmental Movement,” Environmental History 5, no. 1 (2000): 6.
} 
accomplishing that goal. However, the environmental movement in France did not bring about the desired effects its proponents, a weaker centralized government; it illustrates how discontent among the masses can spawn the genesis of a major social movement. The rise of the counterculture in the late 1960s and early 1970s similarly interacted with the environmental movement and appeared, although in a modest fashion, at the United Nations Conference on the Human Environment.

The environmental movement in Soviet Union controlled Czechoslovakia illuminates how environmental thought became part of the globalization process in the 1960s and 1970s. The Soviet Union, under its five-year plans, sought to industrialize exponentially. In the satellite states, such as Czechoslovakia, this caused rampant urban-escapism as people sought to get back to nautre. ${ }^{71}$ Individuals from these states became more environmentally conscious. This development led to the creation of a few ENGOs including the Nature Conservation Section under the auspices of the National Museum Society. ${ }^{72}$ From this organization sprouted a more organized environmental group, comprised of experts on the conservation, called Tis. This organization lost funds from the government because their goals conflicted with the industrially minded goals of the USSR. In order to raise funds, the experts started consulting with national agencies and later began exporting their knowledge to Third World countries such as Peru, Kenya, and Vietnam. ${ }^{73}$ Internationally, environmentalism was a joint effort of scientists, politicians, and grassroots movements. ENGOs in the Soviet bloc were part of the process of environmental globalization. These organizations, similar to ENGOs in the United States, began building transnational networks and devising programs with globally oriented goals. This

\footnotetext{
${ }^{71}$ Philip Sarre and Petr Jehlička, "Environmental Movements in Space-Time: The Czech and Slovak Republics from Stalinism to Post-Socialism," Transactions of the Institute of British Geographers 32, no. 3 (2007): 350.

${ }^{72}$ Ibid.

${ }^{73}$ Ibid, 351.
} 
becomes an important strategy for ENGOs at Stockholm and an important development in NGO diplomacy in the early 1970s.

\section{The Cold War}

Development, Modernization, and the Cold War

The Stockholm Conference was a meeting to confer on the status of the human environment and discussion about the condition of the environment often concerns the forces that degrade it. As Mostafa Tolba, former director of the United Nations Environmental program wrote, "The Stockholm Conference clarified the link between development and the environment and suggested an approach that would recognize the socioeconomic factors behind many environmental problems and cure the effects by treating the causes." ${ }^{, 74}$ Therefore, in order to understand the actions of the diplomatic actors in Stockholm, we must discuss the forces behind the environmental perils that these agents faced.

Economic development has become an increasingly popular topic among Cold War historians. Globalization is an important part of their narrative. Thomas Friedman writes in his book The World is Flat that the world has gone through three different epochs of globalization, of which the first two I will discuss here. Globalization 1.0, which he argues lasted from around 1492-1800, shrunk the world from large to medium. Essentially, countries were able to make their world smaller through advances in technology and greater accumulation of capital. ${ }^{75}$ Globalization 2.0 lasts from 1800-2000 and notes the ability for private enterprises to become part of globalization. ${ }^{76}$ The Cold War exhibited elements of the first two epochs for the United States and private financial organizations, maintaining global reach and economic development,

\footnotetext{
${ }^{74}$ Mostafa Tolba and Iwona Rummel-Bulska, Global Environmental Diplomacy: Negotiating Environmental Agreements for the World, 1973-1992 (Cambridge: The MIT Press, 1998), 2.

${ }^{75}$ Thomas Friedman, The World is Flat: A Brief History of the Twenty-First Century (New York: Farrar, Straus and Giroux, 2006), 9.

${ }^{76}$ Ibid, 10.
} 
as historians have noted, was a method through which they exerted their power and sought to protect their interests. In tandem with the focus on the Third World after September 11, economic development has become an important topic in diplomatic historiography.

The ideological foundation of development, though it is commonly recognized as a Cold War strategy, was established during the Enlightenment. This intellectual revolution emphasized scientific thought and reason as the driving force behind progress and decision-making. As historian Joe Hodge wrote in the case of the British Empire, "What made this 'second' British Empire distinctive were the ideological currents of the Enlightenment. The doctrine of improvement gave its adherents faith and confidence in their possession of new modes of knowledge and new abilities to shape and manipulate nature to their will."77 The ideological components of development were not the only aspects of economic development to come out of the Enlightenment. Rather, the Enlightenment taught that past errors could be corrected through the use of science and reason. ${ }^{78}$ Therefore, out of the Enlightenment came programs in which people thought could better their world. Many of the proponents of modernization theory and development programs believed innovations in the scientific community would solidify their position as lords over their domain and give them the ability to control the environment around them. ${ }^{79}$ This Enlightenment notion of power translated well into a post-World War II setting.

\footnotetext{
${ }^{77}$ Joseph Hodge, The Triumph of the Expert: Agrarian Doctrines of Development and the Legacies of British Colonialism (Athens: Ohio University Press, 2007), 26.

${ }^{78}$ Thomas Hankins, Science and the Enlightenment (New York: Cambridge University Press, 1985), 2.

${ }^{79}$ The difference between modernization and development is important. Modernization is the process by which a country, region, or other entity makes its way into modernity. The idea of modernity is relative but for the United States, political and economic modernity meant the establishment of democracy and capitalism. In essence, modernization is more of a philosophical construct of an entity's values. Development, whether economic, political or cultural, is a set of specific policies or programs created to bring a region or country into modernity. Development is a more tangible process. Together, modernization and development created important policies and projects during the Cold War.
} 
Social scientific and modernization policies drew from Enlightenment era ideas of western superiority and fit them into a Cold War context. ${ }^{80}$

Between the eras of the Enlightenment and the Cold War, development fit into the context of colonialism. First-world countries used development to show less developed colonies how modernization should look. Furthermore, development was often forced upon these societies. ${ }^{81}$ Development, in this context, was used as an appendage of empire. It served as a tool to form international hierarchies and enlarge spheres of influence for the industrialized powers. Rather than simply as a way to better mankind, it was a tool to emphasize Eurocentrism.

While many Cold War actors used modernization to assert their power, others noticed the more noble aspects of development. The World Bank, Food and Agriculture Organization (FAO), and the World Health Organization (WHO), "helped to create a sense of an international community and an obligation among its members to promote the well-being of the whole." 82 Proponents of modernization saw the benefits development brought in its ability to transform agricultural processes and economic institutions and thereby help cure social ills. "Science could give farmers the ability to grow enough food to feed the world's population on a nutritionally sound basis." ${ }^{83}$ The FAO's goal to renovate agricultural practices, as well as other programs by other international organizations to eradicate global poverty and minimize the impact of diseases, was founded by noble intentions but came with unintended consequences. "In focusing on the end product - development - these international civil servants often overlooked the human

\footnotetext{
${ }^{80}$ Michael Latham, Modernization as Ideology: American Social Science and "Nation Building" in the Kennedy Era (Chapel Hill: University of North Carolina Press, 2000), 14-15.

${ }^{81}$ Nils Gilman. Mandarins of the Future: Modernization Theory in Cold War America (Baltimore: Johns Hopkins University Press, 2003), 29.

${ }^{82}$ Amy Staples, The Birth of Development: How the World Bank, Food and Agriculture Organization, and World Health Organization Changed the World, 1945-1965 (Kent: Kent State University Press, 2006$), 1$.

${ }^{83}$ Ibid, 64.
} 
misery and social disruption caused by industrialization., ${ }^{, 4}$ Prominent among these consequences was the destruction of the environment but in the Cold War, the preservation of the environment took a back seat to the fight against Communism.

Development programs were an effective strategy used by American policy makers during the Cold War. Michael Latham argues that modernization was a comprehensive response to Communism. ${ }^{85}$ In areas such as Latin America, US policy makers believed that political and economic instability invited Communism. Therefore, the United States initiated development programs and encouraged liberal policies to deal with these potential problems. In this way, the American empire was about political containment and market dominance. ${ }^{86}$ However, these programs did not singularly attempt to promote America's economic and political sovereignty but also illuminated the role of America in the world that Americans constructed for themselves. As Latham noted, "Johnson linked America's global mission with the nation's moral purpose." 87 Programs such as the Peace Corps sought to win the hearts and minds of the world's people and tip the balance in the United States' quest for superiority and credibility. While these programs aimed to benefit the image of the United States abroad, their actions in the Vietnam War challenged their status as benevolent world leaders.

\section{The Vietnam War}

The Vietnam War had a significant impact on the role of the United States in the world. After America's experience in Korea, the Domino Theory ${ }^{88}$ became an intrinsic element of diplomatic strategy. The war grew under the supervision of the Lyndon Johnson administration

\footnotetext{
${ }^{84}$ Ibid, 2.

${ }^{85}$ Michael Latham, Modernization as Ideology, 18.

${ }^{86}$ Ibid, 19.

${ }^{87}$ Ibid, 149.

${ }^{88}$ The Domino Theory was the belief that if one country fell to communism, then others would fall right after. Containment became the response to this theory as the United States felt that countries could not fall to communism if it was unable to spread outside of the Soviet bloc.
} 
and dissent toward the Vietnam War persuaded Johnson to decline his party's nomination in the 1968 election. As Richard Nixon entered office in early 1969, the war became a primary component of his foreign relations platform and Nixon vowed to "end the war and win peace in the Pacific." 89

What started as Johnson's war, quickly turned into Nixon's nightmare. The president argued to the America people that the North Vietnamese represented "Communist colonialism."90 The idea that Soviet Communism was spreading represented justification for American presence in Southeast Asia. The American people, as demonstrated during the Johnson years, showed that they did not agree with that conclusion. The most public displays of dissent were political protests. Public opinion polls show that the American people started feeling more favorably toward demonstrators. Polls from 1969 show that $81 \%$ surveyed believed demonstrators were asking important questions, 50\% thought the Vietnam War was a mistake, and $55 \%$ rejected Nixon's characterization of anti-war protesters. ${ }^{91}$ Nixon was losing the support of the American public for his war effort during the first year of his presidency but as the Stockholm Conference grew closer; his escalation of the war further alienated the populace.

In 1970, Nixon began his Cambodia campaign and therefore showed his commitment to winning the war in Vietnam. In response to the bombings in Cambodia, drastic events such as the Kent State shootings, and the publishing of the Pentagon Papers, the American public reacted with more protests and greater suspicion of the American government. "But there can be little doubt that the outburst came because an unpopular war, that seemed to be winding down, was suddenly and dangerously expanded." 92 The expansion of the war led to a greater number of

\footnotetext{
${ }^{89}$ Jeffrey Kimball, Nixon's Vietnam War (Lawrence: University of Kansas Press, 1998), 40.

90 Ibid, 49.

${ }^{91}$ Ibid, 175.

92 David Levy, The Debate Over Vietnam (Baltimore: Johns Hopkins University Press, 1995), 160.
} 
Americans asking for a total military withdrawal from Vietnam. By 1971, $60 \%$ of Americans favored a total withdrawal of American troops by the end of the year. ${ }^{93}$ By the start of the Stockholm Conference in June 1972, an election year in the United States, the majority of American people and the office of the presidency disagreed on what to do about Vietnam. The American people were not the only population to voice their dissent about the Vietnam War. An international community of protestors questioned the United States and doubted their role as a leader at the Stockholm Conference due to accusations of ecocide in Southeast Asia. This stance became problematic for the U.S. delegation, which nonetheless sought to use the conference as an opportunity to reestablish itself as a benevolent leader in global affairs.

At the time of the conference, members of the U.S. counterculture were most critical of the United States government and their position in world affairs. The counterculture was an important development of twentieth century U.S. history but it is by no means a uniquely American movement. These emerging activists from around the world emphasized the Enlightenment ideal of autonomy and saw intertwined social movements as a medium through which to get rid of war, poverty, and injustice. ${ }^{94}$ The counterculture was defined by two important elements. First is their age. This group of people tended to be younger. ${ }^{95}$ The second was the transformation of ideology. According to Ken Goffman, "Among leftists, and even among some hippies, the new word was revolution ... by any means necessary, and it grew from a whisper to a shout." 96 Revolutionaries from the left sought to transform society and the UN Conference on the Human Environment was an excellent stage to protest. The environment was

\footnotetext{
${ }^{93}$ Ibid, 161.

${ }^{94}$ Ken Goffman and Dan Joy, Counterculture Through the Ages: From Abraham to Acid House (New

${ }^{95}$ Ibid, 285.

96 Ibid, 286.
} York: Villard Books, 2004), 247. 
often the victim of Cold War development strategies and the international socialist community staged their protest the capitalist system in Stockholm in 1972.

Protestors and members of the counterculture movement that showed up in Stockholm and governmental delegates had different goals and ambitions going into the conference. Political debates surrounding topics such as the role of the United States in the world and the aggressors causing environmental degradation shaped the approaches of these actors. The Vietnam War and the counterculture politicized the conference and ENGOs sought to disintegrate the ideological and geographical divisions between governments and concentrate on concrete solutions they felt would protect the environment. Furthermore, the ENGO community, as non-state actors, was often lumped in the same group as the counterculture members at the conference. Understanding the approaches of state and counterculture actors is important in order to understand the strategies, ideologies, and perceptions of the American ENGO community.

\section{Presidential Politics of the 1960s and 1970s}

\section{The Administration of Richard Nixon}

The foreign policy of the Nixon Administration is important in understanding the Cold War and the Stockholm Conference. While Nixon sought to win the Vietnam War, it was becoming clear that the United States could no longer be the unchecked police of global affairs. However, the centrality of the United States was still important to the presidential administration. ${ }^{97}$ To Nixon, the United States had to find a way to become the benevolent leader of world affairs. According to Franz Schurmann, "Nixon was a master mover who used foreign affairs to gain power, thereby to centralize executive authority." 98 Nixon, like Lyndon Johnson, played power politics in world affairs. Policy initiated by the Nixon administration, even in

\footnotetext{
${ }^{97}$ Franz Schurmann, The Foreign Politics of Nixon: The Grand Design (Berkeley: Institute of International Studies, 1987), 2.

${ }^{98}$ Ibid, 67.
} 
multilateral agreements, sought to establish the United States as a leader through either practical means or foreign perception.

The United Nations Conference on the Human Environment fits within this narrative and the efforts of ENGOs often were in response to the national goal of American leadership. While the United States put forward a policy rooted in self-interest, ENGOs emphasized globally oriented goals. This primary difference in the approach of the United States and American ENGOs helps establish the non-state actors in the narrative.

\section{Conclusion}

Political, economic, social, and ideological developments shaped the world that surrounded the conference. Delegates and non-state actors who attended the conference confronted these issues and in turn, these issues influenced the worldview of the various diplomats, official and non-official, present in Stockholm. The issues that have been addressed through this chapter penetrated the walls of the conference and influenced the political climate of the world in 1972. The pre-conference period (1970-1972), laid out the issues and concerns that state and non-state delegates would address. While the next chapter will discuss the institutionalized forums of discussion, the focus will be on the informal arena and the influence of American ENGOs during this formative period of international environmentalism. 


\section{Chapter 2: \\ Fighting for a Successful Conference}

June $4^{\text {th }}, 1972$, on the eve of the United Nations Conference on the Human Environment, the New York Times published an article titled "Crucial First Steps," appropriately titled to welcome the first substantive discussion on environmental regulation. According to this article, "In his years of planning and arranging the Stockholm gathering, Secretary-General Maurice F. Strong has had to do some of the most delicate tight-rope walking, as well as some of the most persuasive selling, done on the international scene in decades." 99 These words rang true as geographic and ideological divides permeated into the formal and informal forums of discussion leading up to the conference. Due to these divides, the Conference was in a position to fail. American ENGOs wanted to the conference to succeed and measured success by the ability for a conference to convene and produce substantial and specific policies concerning the human environment. The four years leading up to the 1972 Stockholm Conference were full of deliberations on issues such as pollution, population control, economic aid, whaling, governance, education, technology, and ocean dumping. Government officials, scientific experts, and engaged citizens came together to set the agenda for the conference but ideological, political, and geographical divisions hindered their ability to cooperate. American ENGOs made these divisions an important part of their approach to the conference. Therefore, the pre-conference period tells much on the conference and how it was interpreted for decades after.

Formal and informal diplomatic agents prepared for the world's first major international conference on man's relation to his environment in different ways, each trying to manipulate the substance or tone of the Stockholm agenda. These groups asked fundamental questions regarding environmental regulation, governance, the role of development, priorities of the environmental

99 “Crucial First Steps,” New York Times, June 4, 1972. 
agenda, and the influence of the political climate on environmental negotiations. American ENGOs, during the pre-conference period, contributed to the discussions on these topics and made their voices heard on these issues. As Gareth Porter and Janet Brown stated, "Non-state actors also exert major and increasing influence on global environmental politics, ${ }^{, 100}$ and American ENGOs used the pre-conference period to make themselves viable diplomatic actors.

In order to understand the impact of the activities of American ENGOs, we must contextualize their efforts. To do this, this chapter will first address the efforts of the international scientific community, the United States government, and briefly the other major nations. The international scientific community ${ }^{101}$ put together two different meetings leading up to the Stockholm Conference, one in Founex, Switzerland and another organized by the Fellowship of Reconciliation. These meetings addressed the balance between the needs of developing and developed countries and the balance between environmental perils and economic agendas, which were important issues frequently discussed by American ENGOs. In addition, this chapter discusses governmental action as ENGOs frequently conversed with the American preparatory committees and the State Department. During this time, American ENGOs frequently "lobbied or pressured their own or other governments to accept a more advanced position toward an issue."102

During the preparatory period, American ENGOs began to engage in formal and informal diplomatic activities, which helped establish the foundation for their relevancy in Stockholm. As the following pages show, these organizations aimed to bridge the myriad of global divisions that

\footnotetext{
${ }^{100}$ Gareth Porter and Janet Welsh Brown, Global Environmental Politics, $2^{\text {nd }}$ Edition, (Boulder: Westview Press, 1996), 31.

${ }^{101}$ I use the term International Scientific Community as a term to discuss scientists who engaged in international dialogue. Dai Dong and Founex, the two major scientific groups discussed within the context of the conference, held diverging goals. The term here is meant to note the transnational discussion, used by experts, to discuss the issues surrounding the human environment.

${ }^{102}$ Gareth Porter and Janet Welsh Brown, Global Environmental Politics, 54.
} 
the conference illuminated. The globally focused approach maintained by American ENGOs differs from the nationally focused program of the official American delegation and therefore alters the American presence during the pre-conference period. Furthermore, their efforts created additional room for political space in the international arena. The issue of the global environment fashioned a convoluted political landscape, through which American ENGOs functioned in formal and informal capacities. This chapter will not focus on specific policies though, as the pre-conference era produced few specific policies, but rather, this chapter will address the ideological foundations of, and rhetorical devices used during the planning stage of the conference in Stockholm.

The two organizations that take primacy in this analysis of the pre-conference period are the Sierra Club and the National Audubon Society. This is the case for a few reasons. First, both were very active at the national level prior to the conference and created international programs during the preparatory era. The transition from nationally to internationally focused programs deserves special focus in the context of the environmental movement of the 1970s. Secondly, The National Audubon Society was unique in the fact that its president, Elvis Stahr Jr., was the only member of the official US delegation that represented an ENGO. Third, the Sierra Club was maybe the most prolific communicator with the State Department's Advisory Committee and the Secretary General of the conference, Maurice Strong. The number of letters, memos, and position papers stored in their archives testifies to their status among the American ENGO community. Lastly, the National Audubon Society and the Sierra Club represent two of the most established organizations at the time. The National Audubon Society represented the old-line, moneyed interests and the Sierra Club was arguably the most recognizable name of the time. ${ }^{103}$

${ }^{103}$ Robert Gottlieb, Forcing the Spring: The Transformation of the American Environmental Movement, 119. 


\section{The International Scientific Community before Stockholm}

The international scientific community was one of the most active groups during the preconference period. During this era, scientists drafted several principles regarding the NorthSouth divide and the priorities of development and modernization projects around the world. The two reports discussed here are the Founex Report, which came out of a meeting by scientists and governmental officials in June 1971 and the Dai Dong Declaration, which was the culmination of a meeting by scientists two weeks before the official U.N. conference. These meetings greatly influenced American ENGOs as they served as important forums for issues critical to the success of the conference. These reports are significant, both for contextualization but for also understanding the issues American ENGOs thought to be important.

In June 1971, experts on the development process convened in Founex, Switzerland to discuss an important problem facing environmental regulation, the North-South divide. Developed and developing countries could not agree on the nature of environmental regulation.

Gerald Leach, a writer for the Washington Post said of the meeting,

Ask almost any environmentalist on the international circuit to name the most significant political event of 1971 and as likely as not he will mention Founex, a totally undistinguished village on the outskirt of Geneva... Founex happens to possess an ugly motel where, last June, almost entirely unnoticed by the world's press and television, something happened that will give the town at least a large footnote in world history. For two weeks a group of economists, scientists, development specialists, and U.N. officials met in Founex's motel to discuss ways of convincing the poorer two thirds of mankind that pollution, resources and all the other environmental problems facing the rich countries were their problems too. ${ }^{104}$

The experts in Founex sought to sell the idea of global environmental regulation to developing countries by bridging the divide between environmental and development interests. In their report, they state that their main objective is to "draw pointed attention to the compelling

${ }^{104}$ Gerald Leach, “3d World Warned on Pollution,” Washington Post , January 20, 1972. 
urgency of the environmental problems that arise out of poverty, to the need for a new awareness of the importance of remedial measures, and above all, to the need for reinforcing the commitment, both nationally and internationally, to the development objective itself." ${ }^{\prime 105}$ The experts authoring this document felt that the causes of environmental degradation in the developing world and the need for modernization projects stemmed from the same problem: underdevelopment. $^{106}$

Central to the beliefs of the Founex experts, was the common goal between environmentalism and the goals of the United Nations Second Development Decade. In the report put out by the scientists, economists, development experts, and United Nations officials, a main argument made was that,

Major environmental problems of developing countries are essentially of a different kind. They are predominantly problems that reflect the poverty and very lack of development of their societies. They are problems, in other words, of both rural and urban poverty. In both the towns and in the countryside, not merely the "quality of life," but life itself is endangered by poor water, housing, sanitation and nutrition, by sickness and disease and by natural disasters. These are problems, no less than those of industrial pollution, that clamor for attention in the context of the concern with human environment. They are problems, which affect the greater mass of mankind. ${ }^{107}$

This approach differs significantly from the Friends of the Earth, which generally advocated for decreased development because they believed that there could not be economic growth without detrimental environmental effects. ${ }^{108}$ Though the Founex Report cited development as the cure for the developing world's environmental problems, several representatives from the developed

\footnotetext{
${ }^{105}$ Miguel Ozorio de Almeida, Environment and Development: The Founex Report on Development and Environment (New York: Carnegie Endowment for International Peace, 1972), 11.

${ }^{106}$ Underdevelopment is the idea that a region or nation has yet to reach modernity. To the United States, underdevelopment could be cured by economic growth, through the concept of economic liberalism.

${ }^{107}$ Miguel Ozorio de Almeida, Environment and Development: The Founex Report on Development and Environment, 6.

${ }^{108}$ Friends of the Earth, The Stockholm Conference - Only One Earth: Introduction to the Politics of Survival (London: Earth Island, 1972), 158.
} 
world resisted a double standard in regards to environmental regulation and felt that it would disturb the global economy.

Inconsistent levels of environmental regulation, developed and developing countries argued, could significantly hurt global trade. The report stated that, "There is a fear that the insistence of the developed countries on rigorous environmental standards of products exchanged in international trade may well give rise to a "neo-protectionism.","109 Without strict environmental regulations in the developing world, prices for materials from those regions would be lower and it would give an advantage to those countries. In return, representatives from developing countries believed that, "Rich nations might discriminate unfairly against the products of poor nations on environmental grounds. ${ }^{110}$ In order to quell the harsh debate on the effects of environmental regulation on international trade, the report recommended that, "Potential economic frictions resulting from environmental improvements should be confronted and negotiated through international trade organizations." ${ }^{\prime 11}$ The overall Founex plan to save the environment is similar to the proposals given by the United Nations Development Program to one of the conference preparatory committees, recommending that several environmental problems stem from the development process and can be solved by the development process, as long as environmental problems are considered during the development planning process. ${ }^{112}$

Lastly, an important issue the Founex Report discussed was the issue of governance.

While ENGOs often advocated for increased international authority, the report disagreed.

Gladwin Hill, a prolific journalist on international environmental issues noted that,

\footnotetext{
${ }^{109}$ Ozorio de Almeida, Environment and Development, 30.

${ }^{110}$ Gladwin Hill, "Ecological Hope in a U.N. Bog,” New York Times, September 20, 1971.

${ }^{111}$ Gladwin Hill, “U.N. Group Offers Environmental Plan, Asking 'Reorientation on Man's Values',” New York Times, March 17, 1972.

${ }^{112}$ Speech, Presentation by UNDP at a Prep Committee, January 27, 1971, Box 130, Folder 11, Sierra Club Papers, Bancroft Library, Berkeley, CA.
} 
Another major obstacle that apparently was surmounted was the question of whether local environmental problems, from ocean pollution to the preservation of a vanishing species, call for the creation of some huge new regulatory agency. The overwhelming consensus here is that these problems can be handled within the existing United Nations structure. ${ }^{113}$

The Founex Report called for sovereignty and development and placed it at the center of the environmental debate. The report found compromise between environmental and development concerns and formed what The Guardian called a "sensible international strategy.",114

The Founex Report was significant in addressing the concerns of developed and developing countries, which was an important issue for American ENGOs. Groups such as the Sierra Club, Friends of the Earth, and the National Audubon Society knew that the North-South divide would render the conference useless, if not addressed. This report, though it disagreed on principle points with more ideological organizations such the Friends of the Earth, worked to bridge some of the staggering gaps. The Dai Dong Declaration on the other hand, fit in well with the agenda put forward by American ENGOs before the conference.

Dai Dong, a group sponsored by the Fellowship of Reconciliation, ${ }^{115}$ an international peace movement, authored a declaration on the environment two weeks before the conference. This organization, made of scientists from various countries but primarily the United States, "attributed the environmental crisis to an "interaction between the social and natural systems on this planet'."116 In other words, this group believed the structure of the global system was at the root of environmental degradation. In their declaration, authored just before the conference, the group wrote, "It has become clear that a more rational distribution of industrial power is

${ }^{113}$ Gladwin Hill, “Ecological Hope in a U.N. Bog,” New York Times (New York, NY), September 20, 1971.

114 “One-Earth Strategy,” The Guardian, June 5, 1972.

115 The Fellowship of Reconciliation is an international religious organization, founded in the early $20^{\text {th }}$ century. The original goal of the organization was to promote peace. At the time of the conference, Dai Dong saw environmental justice as an important aspect of international peace.

${ }^{116}$ Gladwin Hill, “Draft Calls for Ecological Responsibility,” New York Times, June 7, 1972. 
necessary if the global problems of environment and society are to be solved." ${ }^{\prime 17}$ Dai Dong held the belief that unequal distribution of wealth and power led to the exploitation of nations, humans, and the environment.

While Dai Dong's central argument was not well received by national delegations, their declaration served as a symbolic critique of the world economic and social order. Jens Bröndom, European director of Dai Dong contended that the representative structure of the UN made reform unlikely,

"We feel there is an ecological imperative which demands fundamental changes in the global political and economic structure. We believe that the U.N. delegates, as members of sovereign states, will be inclined to defend existing governmental interests. Therefore a voice that speaks for the necessity of such change must be heard." 118

Dai Dong believed NGOs should be more prominent actors in world environmental affairs

because they could address environmental perils in a more internationally minded manner. In an interview with Radio Canada International, Fred Knelman, the prime organizer of Dai Dong said,

Most of us have come to feel that the solution cannot be found within the contemporary nature of nation states within the developed world, whether they are communist, socialist, or capitalist. All of them are hooked on growth and the imperative of power. All of them, in a sense are accentuating and perpetuating the problems. So we feel that there has to be some gigantic, in effect world reconstruction and reordering of society. So it will affect everybody, nobody will win the battle against nature. ${ }^{119}$

The central goal of Dai Dong was not feasible in the short run as nation states were the primary agents of diplomacy, but their de-emphasis on national delegations but rather growth of ENGOs would be realized in part over the next couple of decades. The benefit of the Dai Dong meeting

117 "A Declaration on the Environment," June 8, 1972, RG59 Conference on the Human Environment, Box 1, Folder 3, National Archives II, College Park, MD.

${ }_{118}$ Mark Goldsmith, "Ecologists Issue a Call to Arms," The Guardian, May 22, 1972.

${ }^{119}$ Fred Knelman, interview by Alan Yates, Only One Earth: Documentary Series Drawn from Stockholm Meetings, Radio Canada International, June, 1972. 
was that it addressed the issues without the "confines of official national postures."120 American ENGOs met in a similar way, a couple weeks later during the conference itself.

Overall, Dai Dong added significant provocation before the conference began. Dai Dong argued, in contrast to the report submitted by the experts at Founex, that after the restructuring of the global order, that the "use of... resources, however, should not be dictated by... geography, but must be allocated in such ways to serve the needs of the world's people in this and future generations... The environment is an indivisible whole." ${ }^{\prime 21}$ Their propositions stemmed from an ideology similarly held by participants of the first Earth Day in the United States,

They realized that the unrestrained urbanization and industrialization characteristic of the nation's post-World War II economic boom mandated more than the simple need to use natural resources wisely. It demanded a broader protection for overall environmental quality, protection for the intrinsic condition of the... air, water, and land. Expanding upon the tradition of Progressive-era preservationists, these new environmentalists viewed the earth as an ecosystem with humanity only a part, a part that nevertheless threatened the whole. ${ }^{122}$

The Dai Dong Declaration supported an internationalist view of the environment and placed sovereignty as secondary to environmental preservation. Their findings though, they felt were not confined to the context of the conference. They hoped that Dai Dong was the beginning of an ongoing dialogue about the relationship between the global order and the international environment. ${ }^{123}$ This declaration has significant consistencies with the positions taken by several American ENGOs. The vast coverage Dai Dong received by the media was good news for American ENGOs. The similarities between their positions, which will be discussed later in this chapter, meant that Dai Dong furthered the ENGOs cause in Stockholm.

120 Ibid.

121 “A Declaration on the Environment," June 8, 1972, RG 59 Conference on the Human Environment, Box 1, Folder 3, National Archives II, College Park, MD.

122 J. Brooks Flippen, Nixon and the Environment, 1.

123 "Dai Dong Bangs its Environment Gong," The Guardian, June 8, 1972. 


\section{State Actors before Stockholm}

For the United States, the pre-conference era (1968-1972) was a contentious time in domestic and foreign affairs. In 1969, the first Republican president since Dwight Eisenhower took office. Richard Nixon won a tight election against Hubert Humphrey and George Wallace after President Johnson decided not to run for reelection due to the unpopularity of the Vietnam War. Nixon, burdened by Johnson's war, escalated the conflict and increasing opposition mounted against him domestically and internationally. ${ }^{124}$ Vietnam, in the context of the Cold War, entrenched America's commitment to the policy of containment. The Cold War intensified the distrust between East and West and while Nixon's Détente aimed to ease diplomatic tensions, America still found itself in the middle of a powerful global conflict. World events became the catalyst behind American foreign environmental relations. They emphasized the need for the United States to become the leader of global environmentalism and protect its national interest, namely economic growth in the Third World to protect against communism.

American government officials viewed Stockholm as an opportunity to assert governance in another aspect of the global arena. Before the conference began, Nixon's administration believed America's actions at the conference would perpetuate one of two perceptions Americans had about him. Nixon's supporters viewed him as a “self-controlled paragon of conservative values and a wise defender of the national interests" and his opposition viewed him as "an unprincipled scoundrel who abused the country's democratic institutions." "25 Both interpretations illuminate an important characteristic about the president. Nixon was a political

\footnotetext{
${ }^{124}$ William Berman, William Fulbright and the Vietnam War: The Dissent of a Political Realist, (Kent: Kent State University Press, 1988), 154.

${ }^{125}$ Robert Dallek, Nixon and Kissinger: Partners in Power (New York: Harper Collins Publishers, 2007), 90.
} 
realist in terms of foreign policy, meaning he believed in the ability for powerful countries to manipulate world events and act in their self-interest.

The Administration aimed to project a positive image of itself on the international stage to offset recent events that portrayed the U.S. negatively. The multilateral nature of the Stockholm negotiations provided the United States a platform to project themselves as the benevolent front-runners of environmentalism. Russell Train, the head of the U.S. delegation, wrote in a letter to John Ehrlichman that, "International cooperation on environmental matters constitutes a major opportunity for positive U.S. leadership in world affairs."126 The Vietnam War undercut the humanitarian image that the president sought and the doctrine of containment was designed to engineer. Nixon sought to reshape America's foreign relations and distance the country from traditional policies. Nixon claimed that the policy of containment broke down with Vietnam and the country must come to grips with the presence of China despite its communist nature. ${ }^{127}$ Containment had long been the policy that influenced foreign affairs and Nixon attempted to detach his presidency from that Cold War school of thought. Nixon visited China with a spirit of good faith, something no president had done before him. While his visit was beneficial to the image of the United States, the conference still provided a vital opportunity for the presidential administration to rebuild the nation's image internationally.

The administration prepared for this promising opportunity through participation in international and domestic preparatory committees. An important aspect of Nixon's foreign policy decision making was that, “The most important decisions were made either by Nixon

\footnotetext{
${ }^{126}$ Letter, Russell Train to John Ehrlichman, February 14, 1972, WHCF: Subject: FG 6-17: Box 1: Folder 8, Council on Environmental Quality Papers, Richard Nixon Presidential Library, Yorba Linda, CA.

${ }^{127}$ Chris Tudda, A Cold War Turning Point: Nixon and China, 1969-1972, (Baton Rouge: Louisiana State University Press, 2012), 2.
} 
alone or in consultation with Kissinger"128 and "The theoretical design of the NSC system required a clear hierarchical chain of command intended to protect the president's time and screen information carefully." ${ }^{129}$ In effect, Nixon or Kissinger were not consulted unless a highly sensitive issue came up. Nixon was absent from most of these environmental talks, and Kissinger only weighed in on issues of nuclear sovereignty. Therefore governmental organizations throughout the administration participated in the effort to develop policy for the conference. Inter-Agency groups created for the Stockholm Conference proved to be essential spheres for discussion among government officials. ${ }^{130}$ The domestic committees wrote the U.S. National Report, which was submitted to the United Nations in 1971. This document was the framework for the final position papers and policies. ${ }^{131}$

The U.S. National Report emphasized the primacy of development and modernization projects and that environmental regulation, while important, should not hinder a country's ability to grow. The scope papers were subject to decisions made by international preparatory committees as well. The committees formed by the United Nations voted on the issues that the conference would address. The United States played a key role in these working groups. Russell Train stated that, "The United States took the lead in preparing for the 1972 UN Conference on the Human Environment in Stockholm, shaping agenda as well as final actions." ${ }^{132}$ In the lead up to the conference, the United States played an active part in determining the direction of the conference. One area of interest to the United States was the relationship of development to the

\footnotetext{
${ }^{128}$ Henry A. Kissinger was Richard Nixon's National Security Advisor during the time of the conference.

${ }^{129}$ Asaf Siniver, Nixon, Kissinger, and U.S. Foreign Policy Making: the Machinery of Crisis (Cambridge: Cambridge University Press, 2011), 24.

${ }^{130}$ Letter, Melvin Levine to Henry Kissinger, January 15, 1972, WHCF: SMOF: John C. Whitaker: Box 106: Folder 4, John Whitaker Papers, Richard Nixon Presidential Library, Yorba Linda, CA.

${ }^{131}$ Committee on Foreign Relations for the United States Senate, United Nations Conference on Human Environment, (Washington: US Government Printing Office, 1972), 6.

${ }^{132}$ John Barkdull, "U.S. Foreign Policy and the Ocean Environment: A Case of Executive Branch Dominance," in The Environment, International Relations, and U.S. Foreign Policy, ed. Paul Harris (Washington: Georgetown University Press, 2001), 138.
} 
environment, which was no surprise, since development has long been a tool used to ensure political and economic stability in Third World countries and a key strategy in Cold War foreign relations. While development took several forms, delegations at the conference focused on economic and industrial development as those that posed the greatest threat to environmental interests.

The preparatory groups discussed pressing environmental issues along with the role of development in world affairs. The committees separated the issues into three general areas: human settlements, natural resources, and pollution and nuisances. ${ }^{133}$ These three areas covered important aspects of development projects carried out by developed countries over the past couple of decades. After World War II, the United States, as an extension of the Marshall Plan, dedicated itself to rebuild Europe and the environment received damage from this endeavor. ${ }^{134}$ The committees focused on the environment in which humans interacted. Protecting the environment became a way to make life better for humans. The U.S. National Report called for a more efficient system to manage resources for the betterment of the country. ${ }^{135}$ The committees sought to protect water, land, and energy reserves to protect the environment and to prevent nonrenewable resources from depleting. Pollution became an important issue in the discussions before the conference. The issue was previously considered a disagreeable but tolerable price for progress. ${ }^{136}$ The United States delegation came to terms that their economic growth outpaced nature's ability to renew itself and that pollution had dangerous consequences. Scholarly

\footnotetext{
${ }^{133}$ United States Department of State, U.S. National Report on the Human Environment (Washington: Department of State Publication, 1971), 1.

${ }^{134}$ The Marshall Plan was an economic recovery plan conceived by George Marshall to rebuild Europe after the catastrophic events that destroyed Europe. The aid packages were also aimed to prevent European nations from slipping into communism.

${ }_{135}$ United States Department of State, U.S. National Report on the Human Environment, 7.

136 Ibid, 17.
} 
literature illuminated these consequences and thus the committees sought to correct decades of neglect through the conference.

Throughout the course of the pre-conference era, some national actors were excluded by the United States, which lobbied, for instance, against the participation of East Germany. The United Nations adopted a U.S. proposed resolution that only allowing U.N. members and affiliated agencies into the conference. ${ }^{137}$ The resolution admitted West Germany but excluded East Germany. Upset by this decision, the USSR and Eastern Bloc boycotted the conference. The Cold War therefore found its way into Stockholm. It is not clear whether the United States sought to exclude East Germany with the intention of antagonizing the Soviets, as officials claimed they wanted to find areas of cooperation with the Soviets, but either way, it destroyed any opportunity to work with Russia and ease tensions through the environment. ${ }^{138}$ The issue of nuclear testing, discussed during the preparation era, embodied similar Cold War tensions and reveals the importance of historical context in environmental negotiations.

The United States made a deliberate effort to maintain nuclear sovereignty and the option to use nuclear weapons despite the negative effects these armaments had on the environment. Paul Harris and John Barkdull argue that state actors move independently of systemic and societal factors and pursue their own preferences and interests. ${ }^{139}$ In the case of nuclear testing, the United States moved away from environmental discourse and aimed to protect their nuclear arsenal, the last resort in Cold War combat. The choice to address nuclear interests diverges from the peaceful foundations of Détente and the spirit of the SALT I treaty, which was signed only

137 “Cold War Environment,” New York Times, February 22, 1972.

${ }^{138}$ Letter, Russell Train to John Erlichman, December 2, 1971, WHCF: Subject: FG 6-17: Box 1: Folder 8, John Whitaker Papers, Richard Nixon Presidential Library, Yorba Linda, CA.

${ }^{139}$ John Barkdull and Paul Harris, "Theories of Environmental Foreign Policy: Power, Interests, and Ideas," in Environmental Change and Foreign Policy: Theory and Practice, ed. Paul Harris, (New York: Routledge Press, 2009), 29. 
three years before. Although different, Nixon's actions at the SALT negotiations and the Stockholm Conference do not contradict each other. The SALT negotiations limited the stockpile and technology that the United States already possessed but a ban on nuclear testing would limit the future of nuclear proliferation. Therefore, the Nixon administration emphasized preserving its nuclear arsenal and sought to secure its nuclear capabilities.

The U.S. government was not unified on the topic of nuclear weapons testing. There was considerable tension between the State and Defense Departments on the wording of their stance on nuclear testing. The State Department submitted a statement for consideration that read, "Meanwhile immense resources continue to be consumed in armaments and armed conflict, wasting and threatening still further the human environment," while the Defense Department stated that, "Due to continuing threats to peace and security, immense resources are being consumed in armaments and armed conflict, threatening still the human environment." ${ }^{140}$ The differences in language are subtle but the delegation's decision to endorse the Defense Department's version illuminates important details about the delegation's priorities. The State Department emphasized the destructive nature of nuclear weapons, while the Defense Department focused on the military and political struggles that made the weapons a necessity. The historical reality of the Cold War influenced the delegation and encouraged them to oppose nuclear regulations that limited U.S. defense options. The United States actively sought to protect its interests in the conference, but despite its efforts, Stockholm also presented an uncertain future as no politician or environmentalist knew for certain what would materialize out of the conference.

\footnotetext{
${ }^{140}$ Letter, Marshall Wright to Henry Kissinger, January 10, 1972, WHCF: SMOF: John C. Whitaker: Box 106, Folder 4, John Whitaker Papers, Richard Nixon Presidential Library, Yorba Linda, CA.
} 
The conference highlighted growing environmental consciousness and sought to address issues such as environmental responsibility and global governance. The motto of the conference was "Only One Earth" therefore signifying that man was part master and part creature in relation to the world. ${ }^{141}$ According to this idea, countries could no longer rule autonomously and independent of environmental factors. The conference represented a world that could exist and was cognizant of and responded to environmental crises in a globally responsible fashion. It then signified a way to construct this new world. A multilateral conference served as a management function in which to govern the global environment. ${ }^{142}$ The United Nations Conference on the Human Environment symbolized the transition from national to global governance of the environment. The conference was the beginning of a process aimed at ultimate global control of the environment. ${ }^{143}$

The ideological underpinnings of the conference and the political realities of the conference show contradictions. One-worldism, an idea that the spirit of the conference advocated for, contradicted the ideology behind U.S. foreign policy objectives. The United States sought to establish itself as the main anti-communist force during the Cold War and attempted to do this through the Truman, Eisenhower, and Nixon Doctrines. The U.S. sought to use the U.N. as a forum for discussion that it could guide toward American diplomatic goals. The United States interpreted Stockholm as an opportunity to assume leadership and protect national interests rather than relinquish sovereignty.

Modernization theory argues that economic growth was an important aspect of deterring a country from communism; therefore, strict environmentalism posed a threat to the United

141 “UN's '72 Motto: Only One Earth,” New York Times, June 14, 1971.

142 Peter Thatcher, "The Role of the United Nations," in The International Politics of the Environment: Actors, Interests, and Institutions, eds. Andrew Hurrell and Benedict Kingsbury, (New York: Oxford University Press, 1992), 188.

${ }^{143}$ Committee on Foreign Relations, United Nations Conference on Human Environment, 30. 
States' interests in Third World. To America, Stockholm symbolized potential conflicts with developing countries. American politicians interpreted development as an instrument used to provide opportunities for all people to have a better life. ${ }^{144}$ Therefore, development was not the antagonist to the environment, but rather an additional method to improve life on the planet. Officials from the United States sought to improve their relationship with Third World countries through development. The Nixon administration pledged to help developing nations cope with environmental problems that arose out of industrialization and urban growth. ${ }^{145}$ Stockholm embodied the possibilities of new relationships with Third World countries and future commitments to the developing world. But despite these hopes and aspirations, it was uncertain how much effect the conference would have on the future of the global environment.

The environment was in dire need of help in the early 1970s. Scholar Erwan Fouere argues that environmental dangers loomed large in 1972, but the promise of international cooperation could control environmental problems. ${ }^{146}$ The conference presented a viable option for world leaders to address environmental issues, but the negotiations would not be without its limits. A New York Times article argued that the conference would not be able to counter all of the problems that people have predicted for the environment. ${ }^{147}$ The future of the globe was uncertain to policymakers at the conference, but America's future role in the world was also at stake as governance, Third World relations, and the prospect of environmental security would all play out in Stockholm.

\footnotetext{
${ }^{144}$ Secretary of State Advisory Committee, Safeguarding Our World Environment, 19.

${ }^{145}$ Speech, Richard Nixon's Second Annual Report on Environmental Quality, September 23, 1971, WHCF: Subject: FG 6-17: Box 1: Folder 7, Council on Environmental Quality Papers, Richard Nixon Presidential Library, Yorba Linda, CA.

${ }^{146}$ Erwan Fouere, "Emerging Trends in International Agreements," in International Environmental Diplomacy: The Management and Resolution of Transfrontier Environmental Problems, (New York: Cambridge University Press, 1988), 30.

147 “Crucial First Steps,” New York Times, June 4, 1972.
} 
The pre-conference era before Stockholm presented the United States with an opportunity to shape its image and position in world affairs. The preparatory committees allowed policymakers to direct the agenda and discussion during the conference and establish itself as a leader in environmental matters. Their position on nuclear testing and the admission of East Germany into the conference embodied the Cold War tensions that surrounded the conference and influenced the policies submitted to the United Nations. The U.S. goals for the future shaped the actions of U.S. representatives during the pre-conference era. All of these factors fashioned a conference that changed the way people perceived the environment and forever altered the characteristics of environmental negotiations. American ENGOs often clashed with policies set by the United States but as the following section shows, ENGOs often communicated with other groups and sought to act as diplomatic brokers during the pre-conference period.

\section{American ENGOs before Stockholm}

The modern environmental movement in the United States emerged in several stages. Even before the rise of these organizations, engaged citizens were active in the public policy debate over the environment as the discussion found itself in the court of public opinion, not the legislative arena. ${ }^{148}$ Citizens became more interested in the environment and environmental organizations became an outlet for activism. Leading up to the pre-conference period, American ENGOs worked to make themselves relevant in the realm of national politics. Organizations such as the Sierra Club and the National Audubon Society played instrumental roles in helping the modern environmental movement gain momentum. During the 1960s and 1970s, these organizations grew with an impressive rate,

Between 1960 and 1969, membership in established organizations increased as Americans became aware of environmental problems and as these organizations

\footnotetext{
${ }^{148}$ Jacqueline Switzer, Green Backlash: The History and Politics of Environmental Opposition in the U.S., (Boulder: Lynne and Rienner Publishers, 1997), 131.
} 
became more aggressive about preservation and pollution. While interest was raised in the years preceding Earth Day, a second surge of activity followed. ${ }^{149}$

Environmental activists condemned the post-World War II emphasis on economic development due to its impact on the natural environment. By 1970, these activists questioned industrial society and criticized unrestrained development. ${ }^{150}$

Environmentalism was not inherently American, numerous efforts on the environmental front by American legislators, organizations, and the public, made Americans the most experienced in environmental affairs in the developed world. The United States, by the beginning of the conference, established an agency on environmental issues, passed the Clean Air Act, and instituted the first Earth Day. The United States also had environmental organizations such as the Sierra Club and National Audubon Society that had been working in the field of environmentalism since the Progressive Era. Journalist Marshall Goldman wrote, "For those of us who take pride in leadership, there will probably be some compensation in the fact that the United States is till about five years ahead both in the dimensions of its problems and in the public awareness of what is happening." ${ }^{151}$ Furthermore, the developing world was barely represented among non-state actors due to environmentalism's scarce manifestation in the Third World. According to Barry Commoner, "Environmental concerns are usually voiced by whites," by which he means the developed world. ${ }^{152}$ American ENGOs were some of the most experienced organizations in environmental affairs and their efforts translated into a significant presence in the pre-conference period.

\footnotetext{
${ }^{149}$ JoAnn Carmin, "Voluntary Associations, Professional Organizations, and the Environmental Movement in the United States," Environmental Politics 8, no. 1 (1999): 106

${ }^{150}$ J.R. McNeill, Something New Under the Sun, 356.

${ }^{151}$ Marshall Goldman, "Has the Environment a Future?," The Nation , October 18, 1971.

${ }^{152}$ Barry Commoner, "Motherhood in Stockholm” Harper's Weekly, June, 1972.
} 
The chapter will focus on different ways through which American ENGOs, namely the Sierra Club and the National Audubon Society, functioned during the pre-conference period. These organizations served as part of the Secretary of State's Advisory Committee ${ }^{153}$ for the conference and deliberated policy goals within their organizations. Furthermore, they conversed with the State Department and United Nations concerning the preparatory process and participated in independent international and national conferences on environmental issues in order to prepare for Stockholm.

In regards to ENGO relations with the United States government, these organizations had a difficult time establishing their relevancy within this context. The structure of the conference favored national officials, those authorized to speak on behalf of their governments. ${ }^{154}$ Due to the structure of the Stockholm Conference, the preparation process marginalized non-state actors on a national level. Roger Hansen, a notable environmentalist, criticized the Nixon administration saying, "It seems that the environmental community has been excluded from the UN Conference almost by design." ${ }^{155}$ His frustration reflects the selection of delegates representing the United States in the conference. Out of thirty-five delegates selected, only one represented an environmental NGO. Claiborne Pell, a Democratic Senator from Rhode Island, echoed Hansen's

${ }^{153}$ The Secretary of State's Advisory Committee consisted of 31 members representing organizations such as the League of Women Voters, the Rockefeller Foundation, the Conservation Foundation, the Nature Conservancy, and General Motors. Governmental members included Governor Jimmy Carter, Ambassador to the United Nations George H.W. Bush, and Special Advisor to the Secretary of State on Environmental Affairs Christian Herter.

${ }^{154}$ Secretary of State Advisory Committee, Safeguarding Our World Environment, (Washington: Department of State Publication, 1972), 6.

${ }^{155}$ Letter, Roger Hansen to the Secretary of State's Advisory Committee, October 11, 1971, WHCF: SMOF: John C. Whitaker: Box 106: Folder 4, John Whitaker Papers, Richard Nixon Presidential Library, Yorba Linda, CA. 
disapproval. He condemned the head of the delegation for not making a dedicated effort to consult citizens and the private sphere. ${ }^{156}$

Criticism of nongovernmental exclusion from various national delegations was the focus of several letters to the editors of the London Times and other major newspapers. Launcelot Fleming, Dean of Windsor Castle, wrote to the London Times arguing for their inclusion, "Current environmental problems are unprecedented and require unprecedented solutions... Non-governmental groups should become decision makers with government representatives." ${ }^{157}$ His sentiments reflected popular thought around the developed world. Political awareness and activism was on the rise and NGOs provided citizens a way to interact with their government in a meaningful way. Ralph Verney wrote to the London Times about non-state political inclusion, "Any...government which is courageous enough to lead in this direction will have the widest support of the nation." 158 The environment was an important topic to the public and exclusion of NGOs meant the rejection of the community in policymaking. Nineteenth century historian Alexis de Tocqueville's interest group theory states that public interest groups advocate for the true interests of the people. The national government's exclusion of NGOs therefore meant the exclusion of the people.

While the marginalization of NGOs during the preparation period did limit their official participation, environmentalists and scientists did engage in other forms of debate. Scientists and environmental pundits provoked the debates that preceded the UN Stockholm Conference. ${ }^{159}$ The science community exchanged ideas and the government invited a select few to participate in the

\footnotetext{
${ }^{156}$ Committee on Foreign Relations for the United States Senate, United Nations Conference on Human Environment, 5.

${ }^{157}$ Launcelot Fleming, "Stockholm Conference," The London Times, April 24, 1972.

${ }^{158}$ Ralph Verney, "Stockholm Conference," The London Times, May 4, 1972.

${ }^{159}$ David Adamson, Defending the World: The Politics and Diplomacy of the Environment, (London: I.B. Tauris, 1990), 29.
} 
Secretary of State's Advisory Committee for the conference. While the committee was an official extension of the State Department, their influence in policymaking was minimal. The National Report, which formed the foundation of U.S. policy, was published in 1971, a full year before the advisory committee met for the first time in 1972. In effect, the committee was similar to an unofficial forum for discussion among non-state actors but did not offer NGOs full participatory status before the conference.

There is still much that can be learned from the Advisory Committee, though its effect on the U.S. delegation was minimal. The advisory committee traveled to six different cities across the United States including New York, Cleveland, and Denver in order to hear the concerns of citizens, scientists, and ENGOs. The Sierra Club made an appearance and testified at all six locations. The testimonies show a number of issues the Sierra Club was primarily interested in, such as the priorities among development and environmental interests, clean air and water, economic assistance to help developing countries adhere to new environmental standards, pollution, urban affairs, and population growth. In the New York hearing, Patricia Rambach, head of the Sierra Club's New York office and organizer for the Sierra Club at the conference stated in her testimony that, "It (the Sierra Club) is also deeply concerned that the final declaration be one that identifies the highest goals possible for mankind. It should not be a document merely recording the greatest common denominator of acceptance. ${ }^{160}$ In this instance, the Sierra Club shows noticeable consistency with scientists from Dai Dong by urging internationalist mentality rather than conforming to national policy. In addition, the Sierra Club's stance on population growth urges policy that is for the betterment of mankind rather than what is agreeable at the lowest level. Rambach, during her testimony, accused the current draft of the

\footnotetext{
${ }^{160}$ Speech, Testimony to the Secretary of State's Advisory Committee on the United Nations Conference on the Human Environment, March 3, 1972. Box 130, Folder 13, Sierra Club Archives, Bancroft Library, Berkeley, CA, 1.
} 
Declaration on the Human Environment of not taking population control seriously. ${ }^{161}$ Developed countries, in the pre-conference era, failed to discuss population control substantively in order to appease developing countries. The Sierra Club felt that if population growth could not be controlled, adequate food supplies would plummet and industrialization would skyrocket. ${ }^{162}$ In March 1972, at the Denver session of the Advisory Committee, Brant Calkin, an organizer for the Sierra Club in the Southwest, offered his testimony, which rather than providing specific policy guidelines, presented the committee with a general premise through which to form policy. Calkin preached, "Once hunger is abated, comes a resentment with the loss of clean air and clean water and with the loss of wildlife and human cultural values." ${ }^{, 163}$ His statement was in response to the findings of the Founex Report, which found the development process to take primacy over environmental regulation. Calkin's experience in New Mexico, according to him, related to the situation in the Third World. He characterized each as a region craving development but argued that the environment should not be neglected in order to produce industrial or economic gain. This statement represents policies advocated for by American ENGOs through the Advisory Committee but their more ideological approach failed to make its way into the official policy guidelines of the US delegation.

Though it is doubtful the Secretary of State's Advisory Committee had significant impact on the US delegation, one can still appreciate the existence of a forum for non-state actors to promote their views to the public and government officials. The Advisory Committee allowed American ENGOs to share their positions and advocate public involvement in a very visible manner. As Ross Vincent, a notable environmentalist, said about public involvement,

${ }^{161}$ Ibid, 4.

${ }^{162}$ Ibid, 4.

${ }^{163}$ Speech, Testimony Before the Secretary of State's Advisory Committee on the United Nations Conference on the Human Environment, March 7, 1972. Box 130, Folder 13, Sierra Club Archives, Bancroft Library, Berkeley, CA, 1. 
What we need is informed public opinion. There's a lot of pressure on the State Department to close its policy making off from even this much of public input. But the door has been opened a little, and I think we've got a steel-toed shoe in the door. ${ }^{164}$

The testimonies of the American ENGOs at the Advisory Committee may not have immediately influenced foreign policymaking, but their participation and the participation of numerous other individuals certainly made an example of their relevancy in global environmental affairs.

To prepare for this entrance into the arena of global environmentalism, several American ENGOs worked internally to prepare for deliberations in Stockholm. Furthermore, they constantly communicated with the State Department and Maurice Strong, to encourage them to embrace the concept of unity, rather than political, national, and ideological divisions. These organizations, of which the Sierra Club will be the primary example, previously worked extensively at the national level as they routinely labored to promote environmental efforts. Derek Osborn, an environmental scholar and active member in several ENGOs wrote, "Increasingly they (ENGOs) are involved within countries in shaping the environmental agenda. They need to be equally involved internationally." "165 At this time, ENGOs hoped to be active in guiding the legislative program internationally as they had been at the national level. Their recent growth allowed them to connect issues of the local and regional environment to the international level, "The environment can provide a rallying point and a focus of collective effort at all levels of activity, in the home and locality just as in the great issues of world politics. The great issues can inspire the small and local and lend them significance."166 The ENGO efforts before and during the United Nations Conference on the Human Environment provided a venue through

\footnotetext{
${ }^{164}$ Lynn Langway and Jerry Edgarton, “The U.S. at Stockholm,” The Nation, July 10, 1972.

165 Derek Osborn, "Moving the World Forward," RSA Journal 146, no. 5487 (1998): 94.

166 Ibid.
} 
which these organizations could legitimize international programs and energize their constituencies at home.

During the preparatory period, Sierra Club officials dedicated a significant amount of time and effort ensuring the conference was in a position to succeed. They felt the greatest threat to the success of the conference was ideological and national divisions. Politics plagued the environmental negotiations prior to Stockholm. After the 1971 meeting for the UN Economic Commission for Europe, the Sierra Club wrote to Secretary of State William Rogers, "The Club is upset at the discord which this political issue interjected into the 1971 meeting in Prague... There is no sufficient reason to perpetuate Cold War political patterns into 1972."167 The political issue referred to here was that of universality. The Sierra Club was concerned that incomplete global representation at the Stockholm Conference would result in weak environmental proposals. In regard to this issue, the Sierra Club consistently urged the United States to allow East Germany into the conference and avoid a Soviet protest, but their efforts failed to evoke any support from the U.S. government. Similarly, the Sierra Club conversed with Maurice Strong, the Secretary General of the Conference, to ensure their participation in Stockholm. They notified Strong of their intention to participate in Stockholm, to develop a stronger international program, and requested they be awarded two observer seats at the conference. ${ }^{168}$ These documents are a few of many that display the communication between the Sierra Club and the State Department and United Nations. It is clear that the Sierra Club sought to ensure their presence at the conference and the success of the negotiations.

\footnotetext{
${ }^{167}$ Letter, The Sierra Club to William Rogers, March 2, 1972, Box 185, Folder 6, Sierra Club Archives, Bancroft Library, Berkeley, CA.

${ }^{168}$ Letter, Raymond Sherwin to Maurice Strong, March 3, 1972, Box 185, Folder 6, Sierra Club Archives, Bancroft Library, Berkeley, CA.
} 
In addition to the political divisions the Sierra Club attempted to bridge, the geographic detachment that manifested into the North-South divide, the competing needs and agendas between developed and developing countries. From the perspective of developing countries, an important issue was that of national sovereignty. Bernando de Azevedo Brito, a Brazilian diplomat and member of the United Nations Development Program council, argued that, "The early call for inter-dependence, with its byproduct of a diminishing scope for the very concept of sovereignty, which is so clearly associated with present environmental trends, can jeopardize their (Third World countries) efforts to construct their own societies."169 While Azevedo Brito argued for sovereignty, particularly for the developing world, the Sierra Club held a different position on the issue of sovereignty. Mostafa Tolba and Iwona Rummel-Bulska, both top officials from the United Nations Environmental Program, explain that ENGOs "are often important in urging governments to act but sometimes seek maximum results rather than achievable provisions, to be followed in time by stronger ones, as the more conservative model suggests." ${ }^{170}$ Nationally devised environmental programs often must adhere to national policies and interests whereas ENGOs often advocate for policies they believe will improve the environment on a more macro level.

The Sierra Club monitored and carefully negotiated the North-South divide. Developing countries requested that if environmental standards were to become a part of the development process, that developed countries should increase aid levels to compensate for increased cost, an idea which found little support from developed countries. Patricia Rambach sent a memo out to Sierra Club officials stating this divide as one of the five major difficulties the planning process

\footnotetext{
${ }^{169}$ Bernardo de Azevedo Brito, Meaning and Scope of the Stockholm Conference: From the Perspective of Developing Countries (Ottowa: Institute for International Cooperation, 1972), 20.

${ }^{170}$ Mostafa Tolba and Iwona Rummel-Bulska, Global Environmental Diplomacy: Negotiating Environmental Agreements for the World, 1973-1992 (Cambridge: The MIT Press), 1998.
} 
encountered and "an issue that the Sierra Club should watch closely especially with regard to the UN Development Program activities and International Bank investments." ${ }^{\prime 17}$ While the Sierra Club's stance on the level of environmental regulation differed from the approach of developing countries, according to Rambach's report, they hoped developed countries would meet developing countries in the middle and increase aid levels. As the following paragraphs show, the Sierra Club was often at odds with the State Department's approach to environmental negotiations, but the environmental movement, at this time, contained two important characteristics that made ENGOs viable political agents in the post-war period. First, the importance of dissent and second, that of encouraging public discussion. ${ }^{172}$ Both characteristics of the environmental movement describe the actions of American ENGOs during the preconference period.

The final major efforts in which American ENGOs partook were environmentally focused conferences in the early 1970s. These conferences were forums for American ENGOs to express their views and prepare for the major conference in 1972 but more importantly to build transnational and international networks among environmental organizations. Patricia Rambach, in a letter to Sierra Club officer Eugene Coan, wrote,

In the next few months before the Stockholm Conference, it would be useful for the Club to get in touch with environmental groups in other countries, especially England and the Scandinavian countries, to urge them to put forward their views on the Declaration. If this is of interest, I could put out a letter pointing out some of the weaknesses of the draft and some of the points still at issue, so that the groups would be guided in a similar direction to Sierra Club interests. ${ }^{173}$

\footnotetext{
${ }^{171}$ Report, Report on the Meetings of the Inter-Governmental Working Group on the Declaration on the Human Environment, January 28, 1972, Box 5, Folder 21, Sierra Club Archives, Bancroft Library, Berkeley, CA.

${ }^{172}$ Michael Egan, Barry Commoner and the Science of Survival: The Remaking of American Environmentalism (Cambridge: The MIT Press, 2009), 5.

${ }^{173}$ Letter, Patricia Rambach to Eugene Coan, February 1, 1972, Box 5, Folder 21, Sierra Club archives, Bancroft Library, Berkeley, CA. The Sierra Club sought to create dialogue with organizations from these countries because, as stated in the next chapter, majority of the organizations represented at the conference were either of American or Northern European origin. Therefore, the Sierra Club sought to coordinate with other groups that would be present in Stockholm.
} 
The Sierra Club, before the conference began, sought to manufacture a front representing environmental organizations. As they found out during the conference, this goal would be difficult to achieve.

The National Audubon Society was active in attending conferences during the preparatory period. One conference they were active in was The Rights of Non-Human Nature Conference. The emphasis the NAS put forward at the conference was the need to combine the current environmental situation with the concept of rights,

We believe that there is now a pressing need for systematic interchange among individual thinkers pursuing similar paths in different fields, for a shift of attention to a more positive stage of inquiry, for collective discussion of the advantages and dangers of utilizing the concept of "rights" in connection with the contemporary ecological crisis, and for at least preliminary consideration of the practical implications of the thesis of non-human rights. ${ }^{174}$

These pre-Stockholm meetings allowed ENGOs to discuss and formulate the path they envisioned for a more environmentally friendly future. Conferences became so prolific that Elvis Stahr Jr., president of the National Audubon Society, said "I've also been to (perhaps too) many conferences on the environment." ${ }^{, 175}$ These meeting became venues, outside of the official forums of diplomacy for ENGOs to act in the international arena.

The Sierra Club was increasingly active in international and national conferences. One of these conferences was the 1971 International Youth Conference on the Human Environment, held in Hamilton, Canada. The emphasis the Sierra Club placed on the conference was the growth of public discussion on the environment. Michael McCloskey served on the Board of Directors for the conference and with the help of other organizers, formed Project Maristem.

\footnotetext{
${ }^{174}$ Proposal, Conference Proposal for The Rights of Non-Human Nature Conference, Box B-340, Folder 7 Conference on the Rights of Non-Human Nature, National Audubon Society Archives, New York Public Library, New York, NY.

${ }^{175}$ Letter, Elvis Stahr Jr. to W. Frank Blair, February 18, 1970, Box B-340, Folder 6, Conference on Environment, National Audubon Society Archives, New York Public Library, New York, NY.
} 
This project was a child of the 1971 conference and was a tour of major North American cities and highlighted by youth-oriented public hearings on the global aspects of environmental problems. ${ }^{176}$ The public hearing appear to be organized for two central reasons. First, because official preparations for the 1972 conference occurred with little public input. ${ }^{177}$ And second, to become forums for issues not covered in the Stockholm deliberations such as the role of multinational organizations, population growth, and the role of NGOs. ${ }^{178}$ In addition to the conferences attended by the Sierra Club, they also organized conferences to encourage public participation. In March 1972, they organized a meeting called The Sierra Club Sponsored Seminar on the UN Conference on the Human Environment. The Club wanted the meeting to be a free public outreach event through which information on expectations and intricacies of the conference could disseminate. ${ }^{179}$ Conferences became extensions of Sierra Club programs aimed to encourage a key tenant of their public policy; public participation in the policy making process.

\section{Conclusion}

American ENGOs were active during the preparatory period in establishing their relevancy in international affairs. After decades of working at the national level, these organizations saw the opportunity to elongate the reach of their constituency. These organizations used conferences, advisory committees, and constant communication with official diplomatic groups to make themselves visible in foreign affairs. Furthermore, through these

\footnotetext{
${ }^{176}$ Press Release, Project Maristem, December 3, 1971, Box 130, Folder 11, Sierra Club Archives, Bancroft Library, Berkeley, CA.

${ }^{177}$ Letter, J. Ross Vincent to Michael McCloskey, February 24, 1972, Box 130, Folder 13, Sierra Club Archives, Bancroft Library, Berkeley, CA.

${ }^{178}$ Letter, J. Ross Vincent to Michael McCloskey, February 24, 1972, Box 130, Folder 13, Sierra Club Archives, Bancroft Library, Berkeley, CA.

${ }^{179}$ Program, Sierra Club Sponsored Seminar on UN Conference on the Human Environment, March 8, 1972, Box 130, Folder 13, Sierra Club Archives, Bancroft Library, Berkeley, CA.
} 
venues, they acted as brokers in an attempt to quell the ideological and geographical divides that threatened environmental negotiations.

Groups such as the Sierra Club and the National Audubon Society were active in undertakings related to the Stockholm Conference in the years leading up to the meeting but they were not the only groups active during those years. Groups like Dai Dong and Founex continued the dialogue on issues such as sovereignty, development, and universalism, issues of great importance to American ENGOs. Lastly, the tense relationship between the United States and American ENGOs in the Stockholm era influenced how the conference materialized and how historians and public policy experts would interpret the conference in years to come. The Nixon administration primarily saw the conference as an opportunity for political gain and marginalized NGOs, a direct contrast to the efforts exhibited by ENGOs, which advocated for the primacy of internationally focused policy and greater participation from ENGOs and the public.

Furthermore, the pre-conference period brings to light the divisions that plagued the conference, divisions that became a priority for ENGOs to address before and during the conference.

As the Stockholm meeting quickly arrived, official and unofficial diplomats prepared for this important moment in world history. The Sierra Club wrote to Maurice Strong and requested for an area of 100 square feet of wall space and 30 square feet of table space, on which to display various printed materials and Sierra Club produced films. ${ }^{180}$ American environmental organizations knew this was a moment to vie for their relevancy in world affairs. Over the last few years, there had been a great deal of coordination between NGOs and the UN in order to organize the Environmental Forum and they hoped to make a splash in Stockholm. ${ }^{181}$

\footnotetext{
${ }^{180}$ Letter, The Sierra Club to Maurice Strong, March 3, 1972, Box 130, Folder 13, Sierra Club Archives, Bancroft Library, Berkeley, CA.

${ }^{181}$ Barry Commoner, interview by Earl Bell, CBS Radio Morning News, May 18, 1972.
} 


\section{Chapter 3: \\ Fighting for a Declaration, a Voice, and Relevancy}

Two months before the conference, the agenda of the conference was made public. Over five hundred pages of preparatory committee reports outlined the issues the delegates planned to discuss including human settlements, energy use, pollution, and whaling but omitting the outstanding issues of population control and nonrenewable resources. ${ }^{182}$ Due to all of the preparation made for the conference, delegates, environmentalists, members of the press, and engaged citizens tuned to Stockholm to see if the pre-conference period produced any substantial policy on environmental issues.

The U.N. Conference on the Human Environment convened from June 5 - 16, 1972 in Stockholm, Sweden. Over one hundred countries met for the first major international forum on the environment and related social issues. During this conference, as nations of the world met to deal with the serious issues that faced the planet, the United States sought to assert itself as the leader of the broader environmental movement. ${ }^{183}$ American ENGOs on the other hand committed themselves to the production of a viable yet non-compromising declaration. The atmosphere in world affairs at the time strongly influenced the actions, rhetoric, and policies of the United States, other governmental actors, and the non-governmental communities. The conference at Stockholm was a challenging time to various constituencies yet, in the words of John Gardner of The Common Cause, also represented "a series of great opportunities disguised as insoluble problems." 184

\footnotetext{
${ }^{182}$ Gladwin Hill, "1,200 Gather in Stockholm for Parley on Environment: Delegates from $90 \%$ of the World Arrive in Stockholm for the Conference," New York Times, June 4, 1972.

${ }^{183}$ Letter, Richard Nixon to Russell Train, June 17, 1972, WHCF: Subject: FG 6-17, Box 1, Folder 8, Richard Nixon Presidential Library, Yorba Linda, CA.

${ }^{184}$ Thomas Friedman, Hot, Flat, and Crowded: Why We Need a Green Revolution and How it Can Renew America (New York: Farrar, Straus, and Giroux, 2008), 170.
} 
American ENGOs hoped that they would find success at the conference. Prior to Stockholm, environmental groups played a valuable role in the conservationist movement by heightening concern of national and global environmental problems. ${ }^{185}$ These organizations sought to advise and engage the debate on the human environment on an international scale as they had on a national level. Success would not come easily though as they competed with the interests of the developing world, Cold War politics, and priorities of the nation state. After the experts at Founex released their report, it was going to be tough to advocate for environmental issues to be considered as the primary aspects of development. Development served as an important aspect of US foreign policy at the time. Through development programs such as the Alliance for Progress, ${ }^{186}$ the US “reframed an ideology that resonated with the nation's previous Western expansion and overseas empire building, America's own historical road to progress, and their power to define and promote movement along it." 187 Therefore, addressing the harm of development, advocating for smarter development planning strategies, and requesting scaled back development programs would be a challenge. Economic growth meant different things to different people and countries. For the developing world, it meant a more prosperous future, for the United States, it was an important aspect of the nation's ideological foundation. These served as formidable challenges to American ENGOs in Stockholm.

In order to act as credible diplomatic agents during this monumental occasion, American ENGOs occupied several roles in order to advise delegates, report on the proceedings, and deliberate important issues. Members of these organizations served as delegates, observers,

\footnotetext{
${ }^{185}$ Paul Wapner, Environmental Activism and World Civic Politics (Albany: State University of New York Press, 1996), 42.

${ }^{186}$ The Alliance for Progress was a set of programs established by the United States in Latin America to promote economic cooperation. Programs targeted key each issues such economic growth, education, and democracy.

${ }^{187}$ Michael Latham, Modernization as Ideology, 108.
} 
commentators, protesters, and educators. My argument in this chapter is twofold. First, I argue that their service in these roles made these organizations more visible on an international scale than ever before, thus helping to build the foundation for their entrance into the arena of environmental diplomacy. Secondly, their efforts in Stockholm transformed the US presence at the conference.

Delegates, members of the press, environmental activists, and international youth showed up in Stockholm to become members of the developing environmental narrative of the world.

The imminent threat of a degraded environment encouraged nations to send prominent delegates.

E.J. Kahn of The New Yorker, in regards to the delegates, wrote,

The conference in Sweden is unusual itself in that it is not of scientists but of nations - a hundred in all, at the latest count. Most of them, it is to be expected, will be represented by Cabinet ministers (the United States will send Secretary of the Interior, as well as eleven senators and congressmen). The eminence of the delegates is almost wholly attributable to Strong's having convinced many heads of state that the matters to be discussed are of immediate and overriding concern. $^{188}$

Members of states though were not alone in Stockholm. Together, with the non-state actors, they formed a conglomerate of ideas, strategies, and priorities concerning the human environment.

They acknowledged though, that this conference was only the beginning of the fight to preserve the international human environment. In order to adequately discuss the conference, this chapter will highlight the conference proper, the People's Forum (or Folklet's Forum), and the NGO Environmental Forum. Within these activities, this chapter will focus on the efforts of the Sierra Club, Friends of the Earth, and National Audubon Society as they served in different functions at the conference and provide a holistic view of NGO activities in Stockholm.

${ }^{188}$ E.J. Kahn, “Environmentalist,” The New Yorker, June 3, 1972. 


\section{The United States at Stockholm Conference}

The United States held a powerful position at the conference. The delegation guided its agenda and discussion, which naturally favored American national interests. The United States understood the power dynamics embedded in multilateral discussions. Observers of the conference generally were more interested in the tangible results of Stockholm but appreciated less the process in which international decisions are made and the politics that went into obtaining a consensus. ${ }^{189}$ The U.S. delegation knew that initiatives agreed upon at the conference were only recommendations that would be voted on during the regular sessions of the United Nations. In a similar way, declarations made only served as guidelines for nations to abide by. With this knowledge, the United States understood that any proposed initiative had to pass through a U.N. vote, with the United States possessing a veto power.

The United States' ideological foundation promoted self-interest but the US delegation also promoted proposals that benefitted the human environment. In Russell Train's address to the United Nations, he stated that the United States top priorities were:

1. Permanent entity within the UN

2. $\$ 100$ Million environmental fund

3. Regional cooperation

4. Strengthen monitoring and assessment of the global environment

5. Coordinating research

6. Support effective international action to help nations increase their environmental capabilities

7. Creation of the World Heritage Trust

8. Support international agreement to control the dumping of wastes into the oceans

9. Cooperative action to protect genetic resources and to protect wildlife

10. Support the establishment of criteria upon which national pollution standards can be based

${ }^{189}$ G. Bruce Doern, Green Diplomacy: How Environmental Policy Decisions are Made, (Toronto: C.D. Howe Institute, 1993), 1. 
11. The identification and evaluation of potential environmental impacts of proposed development activities 190

The approach of the United States was not simple. The US delegation balanced the needs of state and the needs of the world. The delegation encouraged national sovereignty and a nation's right to grow economically but also insisted on measures aimed to help the human environment.

Many of the US proposals came to fruition. The Declaration on the Human Environment contained twenty-six principles through which future environmental negotiations should be based. According to John McCormick, the twenty-six principles can be broken up in five main groups:

1. Natural resources should be safeguarded and conserved, the earth's capacity to produce renewable resources should be maintained, and non-renewable resources should be shared.

2. Development and environmental concern should go together, and less developed countries should be given every assistance and incentive to promote rational environmental management.

3. Each country should establish its own standards of environmental management and exploit resources as they wished but should not endanger other states. There should be international cooperation aimed at improving the environment.

4. Pollution should not exceed the capacity of the environment to clean itself, and oceanic pollution should be prevented.

5. Science, technology, education, and research should all be used to promote environmental protection. ${ }^{191}$

Of the twenty-six principles present in the declaration, ten were aimed at either balancing development and environmental interests or establishing the primacy of development. ${ }^{192}$ The principles broadly aligned with the United States' proposals at the conference. Their experience in environmental affairs and economic capabilities allowed them to negotiate effectively at the conference. The American environmental movement in the 1970s was the culmination of almost

${ }^{190}$ Speech, Remarks by Russell Train, June 1972, Box B-448, Folder 2, National Audubon Society, New York Public Library, New York, NY.

${ }^{191}$ John McCormick, Reclaiming Paradise, 103.

192 United Nations, Report - UN Conference on the Human Environment, (New York: United Nations Press, 1973), 4-5. 
a century long process rooted in the progressive era. ${ }^{193}$ The delegation fought for stricter standards on pollution and resource management but primarily sought to protect development. America's Cold War interests further resonated in their final position on nuclear testing. After adopting the Defense Department's wording on nuclear testing, the United States stood firm and argued that any change in their wording was unacceptable. ${ }^{194}$ The Cold War climate influenced the positions the United States because development was an intrinsic part of US foreign policy. Therefore, development took primacy during the conference and self-interest, rather than environmental consciousness, shaped U.S. policy in Stockholm.

The United States' goal of world leadership was primary to America's representatives and the United States, at times, was met with hostility. China and the USSR sought to establish their positions in world affairs by aligning with Third World countries and boycotting the conference when the U.N. General Assembly excluded East Germany. In addition, the United States faced much opposition to its efforts in Stockholm from non-state actors. The press coverage of the events happening outside the conference negatively affected America's image. The delegation faced resentment from Vietnam War demonstrators and a grandchild of Mahatma Gandhi made a speech denouncing the colonial practices of the United States. ${ }^{195}$ Protesters accused the U.S. of ecocide, or destruction of the natural environment, in Third World countries due to their use of chemical weapons such as Agent Orange and condemned the exclusion of East Germany from the environmental talks. ${ }^{196}$ Contemporary world events not only influenced the formation of policy, but also served as the foundation for resistance against the United States'

${ }^{193}$ Robert Gottlieb, Forcing the Spring, 7-8.

${ }^{194}$ Letter, Department of Defense to Department of State, April 23, 1972, WHCF: SMOF: John C. Whitaker: Box 107: Folder 3, John Whitaker Papers, Richard Nixon Presidential Library, Yorba Linda, CA.

${ }^{195}$ John Whitaker to John Erlichman, June 3, 1972, WHCF: SMOF: John C. Whitaker: Box 106: Folder 4, John Whitaker Papers, Richard Nixon Presidential Library, Yorba Linda, CA.

196 “Environmental Parley Opens Amid Hopes, Conflicting Proposals,” Wall Street Journal June 6, 1972. 
programs. Due to the controversial nature of the environment and the resentment against the United States, the delegation stated that the United States would only participate in future conventions that were consistent with their country's objectives. ${ }^{197}$

Non-American state actors resisted U.S. proposals as well. Lesser Developed Countries (LDCs) struggled against pollution standards advocated for by the United States. ${ }^{198}$ America was not the only group aware of what enhanced environmental regulations could do to economic progress. Third World countries resisted any type of ecological protocols, and China sought to align with these resistant countries and become a leader in Third World affairs. ${ }^{199}$ America's role in the conference, while influential, was contested. The efforts by these actors, however, were ultimately futile. The conference urged many national governments to develop domestic environmental programs, although the programs were relatively diluted from what NGOs advocated for in the pre-conference era. ${ }^{200}$

The United States' agenda at the conference, while they still aimed to protect national interests, called for stronger environmental initiatives. These included initiatives on clean water management, preservation of natural resources during an era of increased urbanization, conservation of living resources such wildlife and ecosystems, and energy resources such as oil. ${ }^{201}$ While the delegation's policies were embedded in self-interest, they were not separated from the historical reality of a growing global crisis. The American delegation claimed that the overall objective of the United States was to raise awareness of environmental problems and

\footnotetext{
${ }^{197}$ Letter, Department of Defense to Department of State, April 23, 1972, WHCF: SMOF: John C. Whitaker: Box 107: Folder 3, John Whitaker Papers, Richard Nixon Presidential Library, Yorba Linda, CA.

${ }^{198}$ Allen Springer, "United States Environmental Policy and International: Stockholm Principle 21 Revisited," in International Environmental Diplomacy: The Management and Resolution of Transfrontier Environmental Problems, ed. John Carroll, (New York: Cambridge University Press, 1988), 50.

199 “Global Environment,” New York Times, June 19, 1972.

${ }^{200}$ James Speth, Red Sky at Morning: America and the Crisis of the Global Environment, (New Haven: Yale University Press, 2004), 86.

${ }^{201}$ U.S. Department of State, U.S. National Report, 8-13.
} 
increase domestic and international capabilities to solve these problems. ${ }^{202}$ In the pre-conference period, the United States confronted domestic environmental catastrophes, such as the Santa Barbara Oil spill in 1969, and these disasters prompted a national response to address the degrading environment. Similarly, international awareness was essential to the implementation of environmental programs on an international scale.

Declarations and recommendations from the conference, however, did not legally bind any participating country. ${ }^{203}$ LDCs and developed countries alike did not have to adhere to any resolution made in Stockholm. Without the growth of environmental political structures internationally, wildlife, oceans, air, and other environmental issues that did not adhere to national boundaries could be negatively affected and hurt American commercial and territorial interests. The U.S. delegation used this call for environmental awareness to establish itself as the leader of world environmental affairs and entrench its domination in multilateral negotiations.

The United States attempted to romanticize the conference in order to elevate their image in world affairs. Russell Train argued that the environment was, "not just a domestic issue but an international one. There is an atmosphere of responsiveness to U.S. initiatives, which leads to the idea of the U.S. as the rational leader." ${ }^{204}$ The delegation used historical precedent, status, and the image of American exceptionalism to construct rhetoric surrounding the conference. The Nixon Administration used public relations to advocate for America's role as the leader of the conference. Delegates, when interviewed, were instructed to tell reporters how Nixon's environmental initiatives had won him worldwide recognition in the field of

${ }^{202}$ Letter, White House to State Department, April 23, 1972, WHCF: SMOF: John C. Whitaker: Box 107 : Folder 3, John Whitaker Papers, Richard Nixon Presidential Library, Yorba Linda, CA.

${ }^{203}$ Elizabeth DeSombre, The Global Environment and World Politics: International Relations for the $21^{\text {st }}$ Century (London: Continuum Press, 2002), 13.

${ }^{204}$ Letter, Russell Train to John Erlichman, December 2, 1971, WHCF: Subject: FG 6-17: Box 1: Folder 8, Council on Environmental Quality Papers, Richard Nixon Presidential Library, Yorba Linda, CA. 
environmentalism. ${ }^{205}$ Delegates used Nixon's environmental agenda to justify America's status in the conference. Pro-American rhetoric was used in the argument in favor of implementing the World Heritage Trust, the international version of the National Park Service. John Whitaker, the Assistant Domestic Advisor for Environmental Affairs, argued that the world needed to "Pick up the uniquely American idea of setting aside parks and other land for conservation."206 America's status as the most eco-conscious country in the world served as justification for their leadership during this transformative time in history.

When rhetoric did not justify their leadership, money served as an appropriate alternative. One of the programs that the delegation argued for was a voluntary fund, which the U.N. Environmental Program could use to support environmental initiatives around the world. In order to encourage the participation of other countries and establish their leadership, Nixon pledged to provide forty percent of a one hundred million dollar fund over five years. ${ }^{207}$ Although others claimed otherwise, political scientist Stephen Hopgood argues that this fund was not created to entrench U.S. domination in world environmental affairs but rather as a simple gesture to help fund environmental programs. ${ }^{208}$ It is unclear to decipher Nixon's intention but it is clear that the United States used the fund as economic justification for their leadership at the conference and world environmental affairs.

\section{People's Forum}

The People's Forum (or Folket's Forum or Life Forum), was an additional quasiconference that took place in Stockholm during the UN meeting. This forum primarily comprised

${ }^{205}$ Letter, Russell Train to John Erlichman, December 2, 1971, WHCF: Subject: FG 6-17: Box 1: Folder 8, Council on Environmental Quality Papers, Richard Nixon Presidential Library, Yorba Linda, CA.

${ }^{206}$ Letter, John Whitaker to John Erlichman, June 3, 1972, WHCF: SMOF: John C. Whitaker: Box 106: Folder 4, John Whitaker Papers, Richard Nixon Presidential Library, Yorba Linda, CA.

${ }^{207}$ Letter, John Whitaker to John Erlichman, June 3, 1972, WHCF: SMOF: John C. Whitaker: Box 106:

Folder 4, John Whitaker Papers, Richard Nixon Presidential Library, Yorba Linda, CA.

${ }^{208}$ Stephen Hopgood, American Foreign Environmental Policy and the Power of the State, 92. 
of international youth, far left-wing activists, and radical environmental organizations. These constituencies met to bring light to a number of issues such as American ecocide in Southeast Asia and issues not discussed at the conference such as biochemical warfare. Overall, the Folklet's Forum aimed to rally public opinion around the issue of imperialism that they felt was at the root of the present environmental crisis. ${ }^{209}$

The activists at the People's Forum sought to bring awareness of environmental destruction in the Third World and connect it with the process of imperialism. Members of the forum asked questions such as, who were the victims of environmental destruction, who benefited from it, and what was the connection between environmental problems and social and cultural factors $?^{210}$ While the US condemned these questions as attempts to politicize the conference, the activists of the Life Forum successfully began to create the link between environmental degradation and social justice. In the same strain as the members of Dai Dong, the People's Forum discovered abuse in the social, political, and economic infrastructures of the world and advocated for their alteration.

The meeting of the People's Forum itself took place at several locations across the city. While the center of the People's Forum was located at a hog farm just outside town, the members of the Environmental Forum allowed the People's Forum to use some of their facilities. At Cardet Field, one of the Environmental Forum facilities, the People's Forum arranged a series of speakers to discuss various environmental and human rights topics. Native Americans of the Black Mesa plateau came to discuss the exploitation of their environment by outsiders, anti-war activists spoke about the war in Indo-China, and various speakers debated the dangers of rising

\footnotetext{
209 “Environmental Parley Opens Amid Hopes, Conflicting Proposals," Wall Street Journal, June 6, 1972.

${ }^{210}$ Wade Rowland, Plot to Save the World, 121-122.
} 
world population. ${ }^{211}$ The speeches given by the members of this forum weaved the narrative of environmental destruction with the processes of colonialism, capitalism, and militarism. All of which, they would argue, are destructive to the survival of mankind.

The Folklet's Forum, while the least organized out of the three major conferences occurring simultaneously in Stockholm, did possess guiding principles outlined by its speakers. First, they felt militarism was a destructive force. ${ }^{212}$ They called for peace and immediate resolution in Southeast Asia. Second, they called for the transformation of social and economic lifestyles of nations. ${ }^{213}$ This spoke to the economic institution of capitalism and racial hierarchies that formed because of colonialism. Lastly, they called for the interdependence of all resources. ${ }^{214}$ They believed natural resources belonged to the world. Furthermore, they believed that nature should not be abused by anyone regardless of national boundaries. While the Folklet's Forum was characterized as a more radical approach to environmental preservation, its ideas were not novel, as they were in line with the ideological strain promoted by the members of Dai Dong.

One instance of the People's Forum's reach at Stockholm was the effort of Greenpeace during the conference. Irving and Dorothy Stowe in British Colombia founded Greenpeace in the 1960s. Originally, the organization focused on anti-nuclear campaigns before focusing on environmental issues. ${ }^{215}$ Greenpeace worked on anti-nuclear testing during the lead up to the conference and made it their primary issue in Stockholm. During the conference, members of

${ }^{211}$ Memo, Pat Rambach to Sierra Club, May 19, 1972, Box 130, Folder 14, Sierra Club Archives, Bancroft Library, Berkeley, CA.

${ }^{212}$ Ibid.

${ }^{213}$ Ibid.

${ }^{214}$ Ibid.

${ }^{215}$ Frank Zelko, Make it a Greenpeace: The Rise of Countercultural Environmentalism (Oxford: Oxford University Press, 2013), 10-11. 
Greenpeace went door-to-door, educating people about the dangers of nuclear testing. ${ }^{216}$ Nuclear testing was fought by several developing world governments but ultimately did not make it into the declaration. Greenpeace felt that their efforts made the issue a hot topic among the delegates and raised awareness among the nations of the world. ${ }^{217}$

The Folklet's Forum represents a prime example of what Paul Wapner calls "world civic politics." This is the notion that activists work across societies and with other activists and organizations in order to indirectly pressure states into acting. ${ }^{218}$ The members of the People's Forum comprised of primarily American and Swedish youth, which in a moment of transnational activism, pressured the United States to respond to their demands. As noted before, the United States delegation denounced the political tone used by the youth. Nonetheless, the ability for activists to get together in protest provides a pristine example of Wapner's principle.

The international youth served as one example of non-state actors working in Stockholm. Organizations such as the Sierra Club (SC), the Friends of the Earth (FOE), and the National Audubon Society (NAS) undertook several efforts in order to raise awareness of environmental issues and manipulate the discourse on the human environment. While these organizations were considered more mainstream to the conference delegates, their effect on policy was minimal. Still, their efforts and documentation bring a new light to interpret the major international conference in Stockholm.

\section{ENGOS at the Stockholm Conference}

Non-state actors suggested more idealistic propositions for the conference. Included in these propositions were the mandate for environmental impact statements from nations,

\footnotetext{
${ }^{216}$ Ibid, 134.

${ }^{217}$ Ibid, 134.

${ }^{218}$ Paul Wapner, "Politics Beyond the State: Environmental Activism and World Civic Politics," World
} Politics 47, no. 3 (April 1995): 312. 
international organizations, and multinational corporations, the creation of a global monitoring network for pollution, and an international effort by all nations to assess the impact of population growth on the environment. ${ }^{219}$ The Secretary of State's Advisory Committee focused on environmental enterprises that the United States could champion. The committee proposed that the United States offer more aid to cultivate environmental projects within broader development initiatives. ${ }^{220}$ The advisory committee placed primacy on the deteriorating environment rather than economic development. The committee did not ignore development but they argued that the fragile state of the natural environment deserved the delegation's focus.

NGOs gathered in Stockholm and held a parallel conference alongside the official meeting and the People's Forum to voice their recommendations. ${ }^{221}$ The three conferences represented various levels of diplomatic activity. The official conference served as the official dialogue of the United Nations, the Environmental Forum acted as a quasi-conference and was loosely sponsored by the United Nations, and the People's Forum proceeded as a meeting of citizen activism with no ties to the official meeting. Over four hundred NGOs participated in the parallel environmental conference. ${ }^{222}$ The parallel conference was designed to divert non-state actors attention away from the conference, in an attempt to minimize their attention to controversial issues discussed at the official conference. ${ }^{223}$ The parallel meeting, endorsed by the United Nations, initiated a tradition of NGO conferences that meet concurrently with U.N. talks. $^{224}$ The official conference marginalized NGOs but non-state actors found a forum in which

${ }^{219}$ Secretary of State Advisory Committee, Stockholm and Beyond (Washington: Department of State Publication, 1972), 3.

${ }^{220}$ Ibid, 122.

${ }^{221}$ Russell Train to John Ehrlichman, March 24, 1972, WHCF: Subject: FG 6-17: Box 1: Folder 8, Council on Environmental Quality Papers, Richard Nixon Presidential Library, Yorba Linda, CA.

${ }^{222}$ Elizabeth DeSombre, The Global Environment and World Politics, 73.

${ }^{223}$ John McCormick, Reclaiming Paradise, 100.

${ }^{224}$ Matthias Finger and Thomas Princen, Environmental NGOs in World Politics: Linking the Local and the Global, (New York: Routledge Press, 1994), 4. 
to present their recommendations and argue for an idealistic program to protect the world environment.

The Sierra Club was an active member of the Environmental Forum and through their archives, a clearer picture of the forum appears. As journalist Philip Shabecoff noted,

Stockholm was the first major foray by the environmentalists into the treacherous arena of international politics. The ability of the environmentalists and their allies in the nongovernmental community to arouse public opinion gave them a permanent role in the politics of international environmental policy-making after Stockholm. ${ }^{225}$

This was a key turning point for environmental organizations and the Sierra Club ensured their visibility during the pre-conference period. The Sierra Club was active, participating in the Environmental Forum, serving as an observer at the conference proper, and rallying public opinion domestically. The Sierra Club provides a meaningful look into the official and tangentially related activities of the conference.

The Swedish UN Association and the National Council of Swedish Youth organized the Environmental Forum, with sponsorship from the United Nations, with the intention of providing a platform for an open an unconstrained discussion about environmental problems. ${ }^{226}$ The Environmental Forum was precisely what Dai Dong called for in its declaration. The Forum expected around 3,600 visitors and lined up prominent speakers such as Anna Erlich, Margaret Mead, and Barry Commoner. Additionally, majority of the participants originated from Sweden or the United States. ${ }^{227}$ The Forum amply represented the developed world but failed to represent the developing world adequately. The forum comprised of lectures, movies, and exhibition halls.

\footnotetext{
${ }^{225}$ Philip Shabecoff, A New Name for Peace: International Environmentalism, Sustainable Development, and Democracy (Hanover: University Press of New England, 1996), 39.

${ }^{226}$ Report, Environmental Forum, May 2, 1972, Box 130, Folder 14, Sierra Club Archives, Bancroft Library, Berkeley, CA.

${ }^{227}$ Björn Bergland, "At the Site of the UN Conference, Nightly Environmental Debates with many Famous Persons," Dagens Nyheter (Stockholm, Sweden), date unknown.
} 
The majority of forum activities took place at the Cinema House, Cardet Field, and the National School of Arts. The quasi-conference failed to produce any alternative declaration but rather served as an arena for uncensored discussion and transnational cooperation.

At the Environmental Forum, the Sierra Club showed films, maintained an exhibit with published materials, and hosted two workshops. The films they showed included Oil Spoil!, Miner's Ridge, The Redwoods, West Chichagof, Follow the Wind to Cousin, and No Room for Wilderness. ${ }^{228}$ These films garnered high attendance from activists and spectators. In addition to the films, they hosted workshops on marine pollution and environmental law, and conservation of wildlife and natural resources. ${ }^{229}$ The workshops they held were in the style of a roundtable in which experts discussed these issues from a purely environmental perspective. The exhibition, films, and workshops illuminate an important priority for the Sierra Club at the conference, environmental education. Their resources served as important mediums through which people could become acquainted with environmental realities undisturbed by political jargon.

The Sierra Clubs' to educate the public about the environment and the Stockholm conference extended beyond the Environmental Forum. The Sierra Club coordinated with the Zodiac News Service, an alternative news agency, to distribute news about the conference to the American public. This strategy is similar to an endeavor taken by the Friends of the Earth during the conference. The Zodiac News Service distributed information to radio stations throughout the Bay Area and to over 200 small market stations nationally. ${ }^{230}$ An important issue in these releases was the issue of whale hunting. The United States proposed a ten-year moratorium on whale hunting which also received support from Western European and Scandinavian countries

\footnotetext{
${ }^{228}$ Memo, Pat Rambach to Sierra Club, May 19, 1972, Box 130, Folder 14, Sierra Club Archives, Bancroft Library, Berkeley, CA.

${ }^{229}$ Ibid.

${ }^{230}$ Letter, Eugene Coan to EIC and Friends, June 23, 1972, Box 130, Folder 15, Sierra Club Archives, Bancroft Library, Berkeley, CA.
} 
but Japan opposed the proposition. ${ }^{231}$ This strategy, while implemented on a small scale, allowed for members of the US public to receive information on the conference from an NGO perspective.

Lastly, the Sierra Club functioned as an observer at the conference proper. Eugene Coan was the Sierra Club's delegate at the conference. He reported on conference activities to the club and discussed important issues to the delegates such as ocean dumping, whale hunting, and additionality; the concept of increasing aid levels to accommodate new environmental regulation. ${ }^{232}$ He also recommended specific action in order to combat any problems that arose. For example, the United States advocated for the creation of a UN environmental fund not to exceed 100 million dollars but opposed the issue of additionality in regards to increasing aid levels. In response to this development, Eugene Coan sent a message to Sierra Club headquarters stating, "We must start a major campaign in Washington on additionality."233 The Sierra Club knew that without additionality, LDCs would not sign on to strict environmental protection. Therefore, their observer status allowed them to monitor conference activities and respond to any threats to the proposed declaration.

The observer status also allowed the Sierra Club to discover the conference's view of the role of NGOs. Coan reported that on the first day of the conference, Maurice Strong stated that "were it not for the NGOs and citizen groups, the conference would not have been held" and that "the new dynamic relationships between these organizations and the UN which has grown out of this conference."234 Maurice Strong admired the NGO community and conversed with them throughout the preparatory and conference periods. Observer status at the UN allowed the Sierra

\footnotetext{
${ }^{231}$ Ibid.

${ }^{232}$ Ibid.

${ }^{233}$ Ibid.

${ }^{234}$ Ibid.
} 
Club to see the plans the UN had for the NGO community, and it looked bright, despite their relative marginalization during the conference itself. From the top of the conference hierarchy, the influence and work of the NGO community were recognized.

The Friends of the Earth, in addition, were a major player for the NGO community. David Brower, its founder, was active in the Sierra Club for several years but felt the Sierra Club and other environmental organizations were not resisting governmental pressures to accept wise use policies strongly enough. ${ }^{235}$ Their primary gift to the conference was the creation of the first environmental newspaper, Stockholm Conference Eco. This newspaper chronicled all of the activities of the conference but primarily educated the reader on the evolution of the declaration and participation of NGOs in the diplomatic process. The newspaper was distributed to delegates and member of the press for free and available for purchase by spectators. Before an adequate discussion on the impact of the newspaper can commence, the political positions of the Friends of the Earth must be discussed in order to understand the newspaper's editorial ideology.

Friends of the Earth was one of the few American based international NGOs of the time and was a more left-wing environmental organization. After the conference, the organization published a book titled Only One Earth: Introduction to the Politics of Survival. This book outlined their policies on a range of issues. Their positions show several differences with the priorities of official government delegates. Their ideological position influenced the articles and editorial capacity of the newspaper.

The Friends of the Earth, in their book, wrote about issues such as international governance, air pollution, forest management, and resource consumption. Among these topics, a consistent ideological strain exists. They argued that man must become more efficient and

${ }^{235}$ Akira Iriye, Global Community: The Role of International Organizations in the Making of the Contemporary World (Berkeley: University of California Press, 2004), 146. 
responsible with what it can manage and learn to leave some aspects, which it cannot manage alone. In regards to forest management, they stated that, "forests can survive without managers but not without guardians." ${ }^{236}$ Similarly, in response to resource consumption, they argued that as a species, man consumes and extracts too much and to combat this, mankind must let nature preserve itself or mankind must invoke stronger regulations to prevent overuse. ${ }^{237}$ In order to guard and manage these resources, they argued for greater international governance housed in the United Nations and other international bodies. ${ }^{238}$ The Friends of the Earth's ideology diverged from the United States' approach in two fundamental ways. First, the Friends of the Earth emphasized the inherent value of natural resources compared to the value of natural resources to humans. Secondly, it emphasized on international governance rather than national sovereignty. ENGOs were skeptical of environmental deliberations within the confines of the nation state and believed international bodies could protect the environment more effectively.

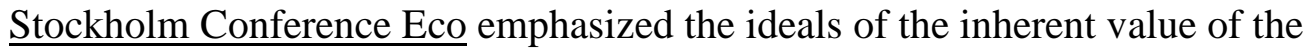

environment and the primacy of international governance in environmental management. While the articles recited facts, the tone of the documents reflects a sense of frustration. The newspaper traced the entire journey of the declaration, from proposal to final product. During the first day of the conference, the newspaper commented on the geographical divisions that threatened the declaration. While Japan, Canada, the UK, and Sweden, part of the committee on environment and development, approved of the draft declaration, Algeria denounced capitalism, imperialism, and racial discrimination. ${ }^{239}$ The developing countries felt that if these issues were not addressed,

\footnotetext{
${ }^{236}$ Friends of the Earth, Only One Earth: Introduction to the Politics of Survival (London: Earth Island Press, 1972), 128.

${ }^{237}$ Ibid, 60 .

${ }^{238}$ Ibid, 118.

239 “First Day Brings Rifts as Expected,” Stockholm Conference Eco (Stockholm, Sweden), June 7, 1972.
} 
they could not approve the declaration. Due to these ideological divisions, the vote on the draft declaration was postponed from June 7 to June 13.

On June 10, nuclear testing, one of the most hotly debated topics of the conference, was discussed. According to Stockholm Conference Eco, Duncan MacIntyre of the New Zealand delegation delivered a passionate speech condemning French nuclear testing. ${ }^{240}$ Major world powers though, would not allow a discussion to commence on nuclear testing since it was vital to their security and tabled the discussion. ${ }^{241}$ The newspaper criticized the national delegations for focusing on national interests instead of the fate of the international environment. As the conference continued, the declaration seemed to be lost. The draft declaration was sent to a closed working group with the objective to produce some compromise. Since environmental problems in the developed and developing world stem from different sources, a US delegate suggested that the group only discuss common problems. ${ }^{242}$ This suggestion meant that the group should only discuss issues that do not include development or industrialization, thereby severely weakening the declaration. The Chinese delegation made matters worse for the declaration. As they sought to obtain leadership of the Third World. The Chinese delegation came out with a declaration condemning capitalism and imperialism and encouraged Third World countries to make amendments on these issues. ${ }^{243}$ This political move sidetracked environmentally focused negotiations and turned the conference into a meeting on human rights. The declaration seemed doomed and the years of negotiations would be pointless.

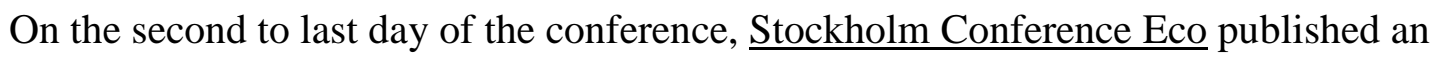
article on the resurrection of the declaration. The United States threatened that if a compromise

\footnotetext{
240 "NZ Slams then Clams," Stockholm Conference Eco (Stockholm, Sweden), June 10, 1972.

241 Ibid.

242 "Declaration Dismembered," Stockholm Conference Eco (Stockholm, Sweden), June 13, 1972.

243 “Declaration Dead?” Stockholm Conference Eco (Stockholm, Sweden), June 14, 1972.
} 
was not reached, there would be no declaration. Soon after, the committees began to pump out principles. It is unclear what compromise each side had to make, but the newspaper stated that it "took a great deal of arm-twisting",244 to reach an agreement. While scholars generally cite this conference as a moment of "political consensus," 245 Stockholm Conference Eco shows that political, ideological, and geographical divisions plagued the conference and sincerely threatened the existence of the declaration.

Lastly, Stockholm Conference Eco adequately covered aspects of the Environmental Forum and other ENGO activities. The newspaper advertised lectures at the forum such as Paul Erlich's talk titled, "Population: The Skeleton in Stockholm's Closet."246 The newspaper also criticized the forum for engaging with, and taking elements from the People's Forum. They accused the forum of containing Marxist monologue and lacking in two-sided debate on the environment. ${ }^{247}$ The instance the newspaper refers to is Barry Commoner's talk at the forum, discussed by Michael Egan in his book about Commoner,

A peace among men must precede the peace with nature... But Commoner also rejected the argument that environmental issues were so innocuous that they served to divert people from more serious, controversial issues, insisting that, "as a political issue, environmental protection is neither innocuous nor unrelated to basic questions of social justice"...He equated environmental hazards with obstacles relating to social progress. ${ }^{248}$

The Friends of the Earth maintained that some of the speakers, including Commoner, were politicizing the conference to an exaggerated extent instead of finding solutions and avenues through which to protect the environment. This is an important aspect of the Environmental Forum. Though the ENGOs were labeled under a single category, it did

244 "Declaration Resurrected," Stockholm Conference Eco (Stockholm, Sweden), June 15, 1972.

${ }^{245}$ Marie Whitesell Balboa, "United Nations Conference on the Human Environment," Women Lawyer's Journal 59, no. 1 (1973): 27.

${ }^{246}$ Advertisement, Stockholm Conference Eco (Stockholm, Sweden), June 8, 1972.

247 "A Funny Thing Happened to the Environment on its Way to the Environment Forum," Stockholm Conference Eco (Stockholm, Sweden), June 14, 1972.

${ }^{248}$ Michael Egan, Barry Commoner and the Science of Survival (Bambridge: MIT Press, 2007), 176. 
not mean that they lacked ideological divisions as well. In this case, they are plagued by some of the same diseases as the state actors. The main difference is in their international focus compared to the government's national focus.

While most of the ENGO activities took place outside of the conference, one important figure, Elvis Stahr Jr., partook in the activities of the official meeting. Stahr was the president of the National Audubon Society and the only member of the thirty-five member delegation to represent an ENGO. In this regard, his experience is unique from the other delegates and organizations. The National Audubon Society, therefore, provides special insight into the workings of the conference.

Stahr was named head United States' delegate for several subcommittees during the conference. He was named head delegate for the committee on conservation conventions and proposed the creation of the World Heritage Trust and a convention on endangered species. He encouraged nations to sign the Wetlands Conservation Convention draft and elected to defer a convention on Islands for Science. ${ }^{249}$ Additionally, he aided the head delegate for the subcommittees on environmental aspects of natural resources and development and environment. He stated that their greatest achievement was the adoption of the ten-year moratorium on commercial whaling, which was only voted against by Japan, South Africa, and Portugal. ${ }^{250}$ The committees Stahr participated in ran relatively smoothly for a divided conference. Stahr later praised the conference and stated, "In the view of experienced United Nations observers, this was the most tightly organized, best managed conference in recent UN history."251 The reports of

\footnotetext{
${ }^{249}$ Memo, Summary of Conference Activities, June, 1972, Box B-448, Folder 2, National Audubon Society, New York Public Library, New York, NY, p. 1.

${ }^{250}$ Ibid, 2.

${ }^{251}$ Ibid, 1.
} 
the Friends of the Earth and the National Audubon Society show that the conference was well organized and the issues were broad but divisions also threatened and stalled negotiations on the environment. Participation of ENGOs in several facets of the conference gives a new nuanced view of international environmental negotiations.

\section{Conclusion}

The Stockholm Conference provided an opportunity for the United States to establish its position as the pioneer of global environmentalism. The delegation's emphasis on the primacy of development and nuclear sovereignty signifies self-interest as the foundation of their approach. While the United States sought to dominate the discourse at the conference, they encountered resistance from, in particular, NGOs, LDCs, Vietnam protesters, and China. These actors questioned and contested the policies and processes, which the United States promoted in Stockholm. America acted with self-interest but also responded to the looming environmental crises of the time and used its position to establish itself as a leader in the conference and broader environmental movement.

ENGOs at the conference on the other hand obtained more internationally focused goals and served in a variety of roles during this new moment in environmental political history. These organizations served as commentators, activists, advisers, delegates, and educators. Their ability to organize and become visible on an international level represents a new era for environmental organizations. One should not overstate their presence though. One delegate for the US delegation stated in an interview, "Everyone was so terribly concerned that the United States might be embarrassed about Vietnam and what we've done to its environment" and they did not like it that "State was pulling the strings. Whenever something difficult, like weapons testing or ecocide came up, we were told to discourage discussion because it might make the United States 
look bad." ${ }^{, 252}$ The journalist of the article wrote that the conference would better be titled "Only One Foreign Policy." ${ }^{, 253}$ Though non-governmental actors were generally excluded from most official forums of decision-making, they practiced diplomacy in several other unofficial capacities. These forums of instruction and deliberation were where American ENGOs vied for their relevancy in Stockholm. After the conference adjourned, nations brought proposals back to their federal governments, other international bodies, and the general assembly. While the conference produced some real results, the idealism of the pre-conference period failed to translate to the post-conference era.

The United Nations Conference on the Human Environment represented a major turning point for American ENGOs. The strategies utilized by these organizations mirrored tactics used on the national level. These groups made an impact on the environmental debate by raising awareness. The Stockholm Conference occurred during an important moment in the history of these organizations. As the number of international organizations grew and national organizations began implementing international programs, this conference was their first major foray into the world of international environmentalism. After the conference, transnational organizations began working to disseminate an ecological sensibility throughout the world. ${ }^{254}$ Now, with experience in the international arena and the organizational infrastructure to face the global environmental debate, American ENGOs headed into the post-conference period with the determination to make significant change on the international level.

The actions of American ENGOs in Stockholm hold much significance. Gilbert Rist, notable scholar on the history of development, notes that NGOs rose in world affairs during the time of structural adjustment and growing neoliberalism of the 1980s. International financial

\footnotetext{
${ }^{252}$ Lynn Langway and Jerry Edgarton, “The U.S. at Stockholm,” The Nation, July 10, 1972.

253 Ibid.

${ }^{254}$ Paul Wapner, Environmental Activism and World Civic Politics, 71.
} 
organizations maintained a greater role in the process of economic development and nongovernmental organizations were designed to give the new order a "human face." ${ }^{, 255}$ While environmental organizations played a greater role in the foreign affairs process in the 1980s and 1990s, their roots in world affairs can be traced back to the Stockholm Conference.

Organizations transformed their infrastructure to accommodate international programs, conversed with the State Department and the United Nations, and educated the public about international environmental affairs. Their essential period of growth was in the 1980s but they formed the foundation of their engagement with world affairs and vied for their relevancy as diplomatic actors in Stockholm.

${ }^{255}$ Gilbert Rist, The History of Development: From Western Origins to Global Faith, (London, Zed Books, 2009), 173. 


\section{Conclusion:}

\section{Fighting for the Earth}

The Stockholm Conference was a new moment in the history of environmental politics. David Twining, a political scientist, wrote of the conference, that it was "the first acknowledgement by the community of nations of new principles of behavior and responsibility for the global environment." 256 The conference served as a symbolic declaration to take progressive steps to preserve and protect the human environment. Novel environmental consciousness was not the only goal of the conference though as delegates hoped to implement real environmental regulation after the conference adjourned. This goal, as state and non-state actors would soon find out, would not come easily. Some actors from Stockholm, such as the U.S. delegation, focused on maximizing public relations potential, whereas ENGOs and some nation states were focused on the environment and helping the Stockholm Conference succeed. As the conference and pre-conference exhibited as well, the post-conference era displayed the diverging responses to environmental regulation.

The post-conference era presented a challenging time for U.S. delegates, politicians, and Nixon administration officials. The delegation achieved many of its objectives and projected a favorable image of the United States, but the future of global environmentalism was still uncertain. After Stockholm, the United States conducted a public relations campaign to publicize its accomplishments to the world. While the United States made a deliberate effort to improve its image, it was inevitably hurt when many of their proposals did not come to fruition such as the moratorium on whaling and initiatives on aimed to slow population growth. Due to the unfulfilled promise of Stockholm, the delegations reconvened in Rio de Janeiro in 1992 to discuss the environment and development. The United States during the post-conference era

\footnotetext{
${ }^{256}$ David Twining, Beyond Multilateralism (Lanham, MD: University Press of America, 1998), 19.
} 
attempted to take control of its image, but political circumstances limited their ability to relay a positive story.

A key strategy for the United States after the conference was to inform the public about their accomplishments. Nixon, in a memo to Russell Train, wrote, "There needs to be an emphasized effort to inform the public about Stockholm." ${ }^{257}$ Nixon called for a public relations campaign to highlight the United States' role in the conference. In addition to relaying America's contribution, the campaign aimed to project Nixon's personal involvement in Stockholm. John Whitaker wrote to John Ehrlichman, "We need to hold a press conference to make sure the president's role in the conference is recognized." 258 The driving force behind the post-conference public relations campaign was the 1972 presidential election. While Nixon did not play a large role in the conference, as his attention was focused on China, his administration played a dynamic role in shaping Stockholm.

The rhetoric of the public relations campaign emphasized the leadership role of the United States but accentuated the goal of global unity. Nixon considered the international environment to be an extension of America's national objectives. ${ }^{259}$ This message was the central theme of Nixon's post-conference media campaign. This message resonated with domestic and international audiences. The United States discovered an area upon which it could build a new positive image in the world. Along with the idea of global unity, the administration emphasized its role as the conferences leader. Train reported to Nixon, "The conference was a huge success,

\footnotetext{
${ }^{257}$ Letter, Richard Nixon to Russell Train, June 17, 1972, WHCF: Subject: FG 6-17: Box 1: Folder 8, Council on Environmental Quality Papers, Richard Nixon Presidential Library, Yorba Linda, CA.

${ }^{258}$ Letter, John Whitaker to John Erlichman, June 18, 1972, WHCF: Subject: FG 6-17: Box 1: Folder 8, Council on Environmental Quality Papers, Richard Nixon Presidential Library, Yorba Linda, CA.

${ }^{259}$ Letter, Richard Nixon to Russell Train, June 17, 1972, WHCF: Subject: FG 6-17: Box 1: Folder 8, Council on Environmental Quality Papers, Richard Nixon Presidential Library, Yorba Linda, CA.
} 
the U.S. played a strong role and attained almost all of its objectives." 260 The sense of victory the U.S. officials felt after the conference became a focal point of the campaign. The sentiment was mirrored in Nixon's presidential address on the conference, which he said, "I am proud the U.S. is taking a leading role in international environmental cooperation." ${ }^{261}$ The dual idea of leadership and unity was the central focus of the public relations campaign after the conference. Domestic recipients of the message heard of their country assuming a leadership role while international viewers perceived a country far from the colonial power they experienced in Vietnam.

Despite the Administration's attempt to remake its image, any action would be limited due to the shortcomings of the conference. Political roadblocks prevented the conference from achieving all it was set out to do. ${ }^{262}$ National and corporate interests prevented many reforms from being implemented and the infantile nature of global environmentalism led to inefficiency in global governance by the United Nations Environmental Program. Aspects of the conference led to weakened proposals. The USSR and Eastern Bloc countries ignored many of the proposals due to their absence at the conference. ${ }^{263}$ A divide between the East and West on environmental issues hindered the prospects of the conference and created a further division in the context of the Cold War.

The North-South divide was highlighted at the conference and during the post-conference era. The debate between developing and developed countries intensified during every environmental conference from Stockholm to Rio de Janeiro, where the 1992 U.N. Conference

\footnotetext{
${ }^{260}$ Letter, Russell Train to Richard Nixon, June 17, 1972, WHCF: SMOF: John C. Whitaker: Box 106: Folder 4, John Whitaker Papers, Richard Nixon Presidential Library, Yorba Linda, CA.

${ }^{261}$ Speech, Richard Nixon's Statement on the Conference, June 20, 1972, WHCF: SMOF: John C. Whitaker: Box 106: Folder 4, John Whitaker Papers, Richard Nixon Presidential Library, Yorba Linda, CA. ${ }^{262}$ Department of State, Report on the UN Conference on the Human Environment, 17.

${ }^{263}$ Claiborne Pell. United Nations Human Environment. (Washington: US Government Printing Office, 1972), 3.
} 
on Environment and Development convened. ${ }^{264}$ While the United States made a distinct effort to protect the interests of developing countries, LDCs perceived any environmental negotiation as a threat to economic progress. Skepticism from developing countries halted the progress made at Stockholm. A lack of state commitment to the Stockholm principles has slowed the environmental movement. ${ }^{265}$ For instance, the ten-year moratorium on whaling proposed by the United States was diminished to a yearly quota on fin and sperm whales by the International Committee on Whaling. ${ }^{266}$ Commercial interests resisted the proposal made by the United States and state actors did not make an effort to support the proposition.

The lack of support by nation states did not stop environmental initiatives completely. The World Heritage Trust, created at the conference, has successfully conserved cultural sites and combined the issues of conservation with cultural and historic memory. The group has worked in developed and developing countries. The United Nation Environmental Program, also created at the conference, governed this body, as well controlled any international environmental initiatives after Stockholm. Despite these efforts, by the late 1980s the environment was still deteriorating. ${ }^{267}$ It is evident that the conference did not live up to its promise. The State Department said, in the Report on the UN Conference on the Human Environment, "Many critics claim it was a poor effort. But perhaps the very fact that there was a conference and that an action plan and a declaration were adopted by large majorities should in themselves be cause for celebration." 268 While the promise of the conference was unfulfilled, the conference itself was a

\footnotetext{
${ }^{264}$ Lawrence Susskind, Environmental Diplomacy: Negotiating More Effective Global Agreements, (New York: Oxford University Press, 1994), 18.

${ }^{265}$ Andrew Hurrell and Benedict Kingsbury, "The International Politics of the Environment: An Introduction," in The International Politics of the Environment: Actors, Interests, and Institutions, ed. Andrew Hurrell and Benedict Kingsbury (New York: Oxford University Press, 1992), 33.

266 "Postscript to Stockholm," New York Times (New York, NY), July 7, 1972.

${ }^{267}$ Maurice Strong, "Global Sustainable Development," in Globalization, Globalism, Environments, and Environmentalism: Consciousness of Connections, 106.

${ }^{268}$ Department of State, Report on the UN Conference on the Human Environment, 14.
} 
major testament to the commitment of nations to address the environmental perils the planet faced. Stockholm represented something new, but the image of the United States is intertwined with the legacy of the conference and that is still undetermined.

In some areas, the conference produced real results. The United Nations, to reward developing countries that made significant progress in the field of environment, created a prize for environmental activities. In October 1972, the United Nations presented Iran with the award for most outstanding contribution to the human environment. The government of Iran set aside areas of land that constituted as an important ecosystem to the United Nations. ${ }^{269}$ This represents an important development after the conference as a member of the Third World took careful steps to improving their environment. Maurice Strong worked with Iran before the conference and advised them on environmental affairs. ${ }^{270}$ Their ideas before Stockholm and the programs it produced after mark an important victory after the conference. To appease the developing world further, the United Nations decided to place the UNEP headquarters in a developing country. The United Nations picked Nairobi as the location and started work there in early $1973 .^{271}$

Environmental negotiations have changed since the 1972 Stockholm Conference and yet there has been significant continuity. After the conference was dismissed, the United Nations Environmental Program, one of the most important products of the conference, assumed the duty of coordinating all international environmental initiatives. ${ }^{272}$ The United States had a strong presence in the program, which answers to the general U.N. body. Furthermore, Stockholm provided the framework for subsequent negotiations including the 1992 United Nations

\footnotetext{
${ }^{269}$ Memo, International Prize for the Most Outstanding Contribution to the Human Environment, October 26, 1972, Box S-0288-0020, Folder 18, United Nations Archives, New York, NY.

${ }^{270}$ Letter, A. Korn to C. Sivasankar, May 10, 1972, Box S-0288-0020, Folder 18, United Nations Archives, New York, NY.

${ }^{271}$ Letter, M. Strong to Odero-Jawi, December 1, 1972, Box S-0288-0020, Folder 19, United Nations Archives, New York, NY.

${ }^{272}$ Lawrence Susskind, Environmental Diplomacy: Negotiating More Effective Global Agreements, 37.
} 
Conference on Environment and Development in Rio de Janeiro. The principles created in the Rio conference mirror the Stockholm Declaration. ${ }^{273}$ More recent environmental conferences do diverge from Stockholm in a major way. Environmental NGOs during latter conferences have been allotted more input in the preparatory processes and conferences proper. ${ }^{274}$ The shift from state to non-state actors has changed the demographics of environmental negotiations and altered the discussion on the balance between development and environmental interests toward an environmental favored discourse. Environmental negotiations are changing but Stockholm played a major role in the way multilateral meetings are conducted.

Environmental organizations transformed in profound ways after the conference. ENGOs became more involved in United Nations activities. In October 1972, the United Nations Association of the USA convened a meeting on US NGO representation in the UN. The association stated that they wished to hold this workshop because,

NGOs and other concerned citizens are increasingly troubled by the silence surrounding UN matters in statements by both political parties, and by the extremely low visibility the UN has in the mass media. The Executive Committee of the Conference of UN Representatives has planned the October $3^{\text {rd }}$ workshop to provide NGOs with information and techniques to help them raise the UN's visibility. $^{275}$

After the conference, the United Nations recognized the value ENGOs brought to their institution and sought to utilize their expertise and ability to mobilize public support. ENGO actions during the conference established their relevancy on the international stage and the United Nations rewarded their efforts with further opportunities for participation.

\footnotetext{
${ }^{273}$ Maurice Strong, "Global Sustainable Development," in in Globalization, Globalism, Environments, and Environmentalism: Consciousness of Connections, 107.

${ }^{274}$ Matthias Finger and Thomas Princen, Environmental NGOs in World Politics: Linking the Local and the Global, 196.

${ }^{275}$ Letter, Conference of UN Representatives to Members of the Conference of UN Representatives and other US NGO Representatives, September 8, 1972, Box B-407, Folder 10, National Audubon Society Archives, New York Public Library, New York, NY.
} 
Ten years after the conference convened, ENGOs looked back at their efforts and recognized the importance of the conference in the transformation of their organizations. NGOs met in May 1982 for the NGO Symposium on Environment and the Future to commemorate the tenth anniversary of the Stockholm Conference. In a letter from UNEP to the NGO representatives, the agency noted that NGOs played a crucial role in the conference. ${ }^{276}$ The meeting noted that NGOs pledged to "live as citizens of a loved yet endangered planet and to share our common heritage with respect for all living things and in justice and amity, with the people of the earth." ${ }^{277}$ The Stockholm Conference, ENGOs realized, symbolized a promise to the environment and to its people. It served as the beginning of their career as diplomatic agents and guardians of the world environment.

ENGOs were vital to promoting environmentalism. As UNEP stated in its time before the 1982 NGO symposium, "During the 1960s, NGOs played a crucial role in promoting awareness among the public and lobbying governments on environmental issues, thereby helping to create the conditions which eventually led to the Stockholm Conference."278 EGNOs, specifically American ENGOs, are important to understanding the Stockholm Conference. Their efforts at the national level forced the creation of environmental consciousness that led to the conference. Furthermore, their actions at the conference paved the way for their relevancy in international environmental affairs in the following decades. American ENGOs are intrinsic to the story of Stockholm and their continuing efforts make a case for their importance in the history of the contemporary world.

\footnotetext{
${ }^{276}$ Letter, UNEP to NGO Representatives, January 1972, Box 5, Folder, 22, Sierra Club Archives, Bancroft Library, Berkeley, CA.

${ }^{277}$ Ibid.

${ }^{278}$ Ibid.
} 


\section{Bibliography}

\section{Primary Sources}

\section{Archival Material}

Conference on the Environment Papers, National Audubon Society Archives, New York, NY.

Conference on the Human Environment Papers, National Archives II, College Park, MD.

Council on Environmental Quality Papers, Richard Nixon Presidential Library, Yorba Linda, CA.

John Whitaker Papers, Richard Nixon Presidential Library, Yorba Linda, CA.

Michael McCloskey Papers, Sierra Club Archive, Berkeley, CA.

Ray Sherwin Papers, Sierra Club Archive, Berkeley, CA.

Sierra Club International Program Records, Sierra Club Archive, Berkeley, CA.

Stockholm Conference Papers, National Audubon Society, New York, NY.

United Nations Papers, National Audubon Society, New York, NY.

\section{Published Sources}

Committee on Foreign Relations for the United States Senate. United Nations Conference on Human Environment. Washington: US Government Printing Office, 1972.

De Azevedo Brito, Bernardo. Meaning and Scope of the Stockholm Conference: From the Perspective of Developing Countries. Ottowa: Institute for International Cooperation, 1972.

Friends of the Earth. The Stockholm Conference - Only One Earth: Introduction to the Politics of Survival. London: Earth Island, 1972.

Ozorio de Almeida, Miguel. Environment and Development: The Founex Report on Development and Environment. New York: Carnegie Endowment for International Peace, 1972.

Pell, Claiborne. United Nations Human Environment. Washington: US Government Printing Office, 1972.

Secretary of State Advisory Committee. Stockholm and Beyond: Safeguarding Our World Environment. Washington, DC: Government Printing Office, 1972.

United Nations. Report - UN Conference on the Human Environment. New York: United Nations Press, 1973.

United Nations. “United Nations Resolution 1346.” July 30, 1968. United Nations Online Archive.

United States Man and the Biosphere Program. Biosphere Reserves in Action: Case Studies of American Experience. Washington DC: Department of State, 1995.

US State Department. Environmental Diplomacy: The Environment and Foreign Policy. Washington D.C.: US Government Printing Office, 1997. 
US State Department. U.S. National Report on the Human Environment. Washington: Department of State Publication, 1971.

\author{
Periodicals \\ Harper's Weekly \\ London Times \\ New York Times \\ Stockholm Conference Eco \\ The Guardian \\ The Nation \\ The New Yorker \\ Wall Street Journal \\ Washington Post \\ Multimedia Sources \\ CBS Radio Morning News \\ Radio Canada International \\ UN General Assembly Resolution Online Archives
}

\title{
Secondary Sources
}

Articles, Book Chapters, Introductions and Forwards.

Balboa, Marie Whitesell. "United Nations Conference on the Human Environment." Women Lawyer's Journal 59, no. 1 (1973): 26-27.

Barkdull, John. "U.S. Foreign Policy and the Ocean Environment: A Case of Executive Branch Dominance." In The Environment, International Relations, and U.S. Foreign Policy, edited by Paul Harris, 134-156. Washington: Georgetown University Press, 2001.

Bess, Michael. "Greening the Mainstream: Paradoxes of Anti-Statism and Anti-Consumerism in the French Environmental Movement." Environmental History 5, no. 1 (2000): 6-26.

Betsill, Michele and Corell, Elisabeth. "Introduction to NGO Diplomacy." In NGO Diplomacy: The Influence of Nongovernmental Organizations in International Environmental Negotiations, edited by Michele Betsill and Elisabeth Corell, 1-18. Cambridge: The MIT Press, 2007.

Carmin, JoAnn. "Voluntary Associations, Professional Organizations, and the Environmental Movement in the United States," Environmental Politics 8, no. 1 (1999): 101-121.

Cohrssen, John. "US International Interests, Sustainable Development, and the Precautionary Principle." In The Greening of US Foreign Policy, edited by Terry L. Anderson and Henry I. Miller, 115-142. Stanford: Hoover Institution Press, 2000. 
Conca, Ken. "Environmental Organizations and the UN System." In NGOs, the UN, and Global Governance, edited by Thomas Weiss and Leon Gordenker, 441-457. Boulder, CO: Lynne Rienner Publishers, 1996.

Cronon, William. "Forward." In Whales and Nations: Environmental Diplomacy on the High Seas, authored by Kurk Dorsey, vii-xii. Seattle: University of Washington Press, 2013.

Dodson, Belinda. "A Soil Conservation Safari: Hugh Bennett's 1944 Visit to South Africa." Environment and History 11, no. 1 (2005): 35-53.

Dorsey, Kurk. "Perhaps I was Mistaken: Writing About Environmental Diplomacy Over the Past Decade." Passport 44, no. 1 (April 2013): 37-42.

Flippen, J. Brooks. "Richard Nixon and the Triumph of Environmentalism." In American Environmental History, edited by Louis Warren, 275-298. Oxford, UK: Blackwell Publishing, 2003.

Fouere, Erwan. "Emerging Trends in International Agreements." In International Environmental Diplomacy: The Management and Resolution of Transfrontier Environmental Problems, edited by John Carroll, 29-44. New York: Cambridge University Press, 1988.

Gottlieb, Robert. "Reconstructing Environmentalism: Complex Movements: Diverse Roots." In American Environmental History, edited by Louis Warren, 245-274. Malden: Blackwell Publishing, 2003.

Harris, Paul. "Introduction." In The Environment, International Relations, and U.S. Foreign Policy, edited by Paul Harris, 3-44. Washington, DC: Georgetown University Press, 2002.

Hurrell, Andrew and Kingsbury, Benedict. "The International Politics of the Environment: An Introduction." In The International Politics of the Environment: Actors, Interests, and Institutions, edited by Andrew Hurrell and Benedict Kingsbury, 1-50. New York: Oxford University Press, 1992.

Jehlička, Petr and Sarre, Philip. "Environmental Movements in Space-Time: The Czech and Slovak Republics from Stalinism to Post-Socialism.” Transactions of the Institute of British Geographers 32, no. 3 (2007): 346-362.

Jian, Chen. "China, the Third World, and the Cold War." In The Cold War and the Third World, edited by Robert McMahon, 85-100. New York: Oxford University Press, 2013.

Johnson, Benjamin. "Conservation, Subsistence, and Class at the Birth of Superior National Forest." In American Environmental History, edited by Louis Warren, 179-210. Malden: Blackwell Publishing, 2003.

Kamat, Sangeeta. "The NGO Phenomenon and Political Culture in the Third World." Development 46, no. 1 (2003): 88-93.

Lawrence, Mark. "The Rise and Fall of Nonalignment." In The Cold War in the Third World, edited by Robert McMahon, 139-155. New York: Oxford University Press, 2013.

McNeill, J.R. and Unger, Corinna. "The Big Picture." In Environmental Histories of the Cold War, edited by J.R. McNeill and Corinna Unger, 1-19. New York: Cambridge University Press, 2010. 
Nash, Gerald. “The West as Utopia and Myth.” Montana: The Magazine of Western History 41, no. 1 (1991): 69-75.

Osborn, Derek. "Moving the World Forward." RSA Journal 146, no. 5487 (1998): 94-99.

Pinchot, Gifford. "The Fight for Conservation." In American Environmentalism: The Formative Period, 1860-1915, edited by Donald Worster, 84-95. New York: John Wiley \& Sons, 1973.

Springer, Allen. "United States Environmental Policy and International: Stockholm Principle 21 Revisited." In International Environmental Diplomacy: The Management and Resolution of Transfrontier Environmental Problems, edited by John Carroll, 45-66. New York: Cambridge University Press, 1988.

Strong, Maurice. “Global Sustainable Development.” In Globalization, Globalism, Environments, and Environmentalism, edited by Steven Vertovec and Darrell Posey, 103122. New York: Oxford University Press, 2004.

Thatcher, Peter. "The Role of the United Nations." In The International Politics of the Environment: Actors, Interests, and Institutions, edited by Andrew Hurrell and Benedict Kingsbury, 183-211. New York: Oxford University Press, 1992.

Wapner, Paul. "Politics Beyond the State: Environmental Activism and World Civic Politics." World Politics 47, no. 3 (April 1995): 311-340.

$\underline{\text { Books }}$

Adamson, David. Defending the World: The Politics and Diplomacy of the Environment. London: I.B. Tauris, 1990.

Anker, Peder. Imperial Ecology: Environmental Order in the British Empire, 1895-1945. Cambridge: Harvard University Press, 2002.

Barkdull, John and Harris, Paul. "Theories of Environmental Foreign Policy: Power, Interests, and Ideas." In Environmental Change and Foreign Policy: Theory and Practice, edited by Paul Harris, 19-40. New York: Routledge Press, 2009.

Barton, Gregory. Empire Forestry and the Origins of Environmentalism. Cambridge: Cambridge University Press, 2002.

Berman, William. William Fulbright and the Vietnam War: The Dissent of a Political Realist. Kent: Kent State University Press, 1988.

Borowy, Iris. Defining Sustainable Development for our Common Future: A History of the World Commission on Environment and Development. New York: Routledge, 2013.

Brown, Janet Welsh and Porter, Gareth. Global Environmental Politics, $2^{\text {nd }}$ Edition. Boulder: Westview Press, 1996.

Dallek, Robert. Nixon and Kissinger: Partners in Power. New York: Harper Collins Publishers, 2007.

DeSombre, Elizabeth. The Global Environment and World Politics: International Relations for the $21^{\text {st }}$ Century. London: Bloomsbury Academic, 2006. 
Doern, G. Bruce. Green Diplomacy: How Environmental Policy Decisions are Made. Toronto: C.D. Howe Institute, 1993.

Dorsey, Kurk. The Dawn of Conservation Diplomacy: US-Canadian Wildlife Treaties in the Progressive Era. Seattle: University of Washington Press, 1998.

Egan, Michael. Barry Commoner and the Science of Survival. Bambridge: MIT Press, 2007.

Finger, Matthias and Princen, Thomas. Environmental NGOs in World Politics: Linking the Local and the Global. New York: Routledge Press, 1994.

Friedman, Thomas. The World is Flat: A Brief History of the Twenty-First Century. New York: Farrar, Straus and Giroux, 2006. . Hot, Flat, and Crowded: Why We Need a Green Revolution and How it Can Renew America. New York: Farrar, Straus, and Giroux, 2008.

Gilman, Nils. Mandarins of the Future: Modernization Theory in Cold War America. Baltimore: Johns Hopkins University Press, 2003.

Goffman, Ken and Joy, Dan. Counterculture Through the Ages: From Abraham to Acid House. New York: Villard Books, 2004.

Gottlieb, Robert. Forcing the Spring: The Transformation of the American Environmental Movement. Washington, D.C.: Island Press, 1993.

Groves, Richard. Green Imperialism: Colonial Expansion, Tropical Island Edens and the Origins of Environmentalism, 1600-1860. Cambridge: Cambridge University Press, 1996.

Hankins, Thomas. Science and the Enlightenment. New York: Cambridge University Press, 1985.

Haq, Gary and Paul, Alistair. Environmentalism Since 1945. New York: Routledge Press, 2012. Hodge, Joseph. The Triumph of the Expert: Agrarian Doctrines of Development and the Legacies of British Colonialism. Athens: Ohio University Press, 2007.

Hopgood, Stephen. American Foreign Environmental Policy and the Power of the State. New York: Oxford University Press, 1998.

Iriye, Akira. Global Community: The Role of International Organizations in the Making of the Contemporary World. Berkeley: University of California Press, 2004.

Jahn, Beate. Liberal Internationalism: Theory, History, Practice. New York: Palgrave MacMillan, 2013.

Kimball, Jeffrey. Nixon's Vietnam War. Lawrence: University of Kansas Press, 1998.

Latham, Michael. Modernization as Ideology: American Social Science and "Nation Building" in the Kennedy Era. Chapel Hill: University of North Carolina Press, 2000.

Levy, David. The Debate Over Vietnam. Baltimore: Johns Hopkins University Press, 1995.

McCormick, John. Reclaiming Paradise: The Global Environmental Movement. Bloomington: Indiana University Press, 1991.

McNeill, J.R. Something New Under the Sun: An Environmental History of the Twentieth Century World. New York: W.W. Norton \& Company, 2001.

Milbrath, Lester. Environmentalists: Vanguard for a New Society. Albany: State University of New York Press, 1984. 
Rist, Gilbert. The History of Development: From Western Origins to Global Faith. London: Zed Books, 2009.

Rowland, Wade. The Plot to Save the World: The Life and Times of the Stockholm Conference on the Human Environment. Toronto: Clarke Irwin, 1973.

Schurmann, Franz. The Foreign Politics of Nixon: The Grand Design. Berkeley: Institute of International Studies, 1987.

Shabecoff, Philip. A New Name for Peace: International Environmentalism, Sustainable Development, and Democracy. Hanover: University Press of New England, 1996.

Siniver, Asaf. Nixon, Kissinger, and U.S. Foreign Policy Making: the Machinery of Crisis. Cambridge: Cambridge University Press, 2011.

Speth, James. Red Sky at Morning: America and the Crisis of the Global Environment. New Haven: Yale University Press, 2004.

Staples, Amy. The Birth of Development: How the World Bank, Food and Agriculture Organization, and World Health Organization Changed the World, 1945-1965. Kent: Kent State University Press, 2006.

Susskind, Lawrence. Environmental Diplomacy: Negotiating More Effective Global Agreements. New York: Oxford University Press, 1994.

Switzer, Jacqueline. Green Backlash: The History and Politics of Environmental Opposition in the U.S. Boulder: Lynne and Rienner Publishers, 1997.

Tolba, Mostafa and Rummel-Bulska, Iwona. Global Environmental Diplomacy: Negotiating Environmental Agreements for the World, 1973-1992. Cambridge: The MIT Press, 1998.

Tudda, Chris. A Cold War Turning Point: Nixon and China, 1969-1972. Baton Rouge: Louisiana State University Press, 2012.

Twining, David. Beyond Multilateralism. Lanham, MD: University Press of America, 1998.

Victor, David. Collapse of the Kyoto Protocol and the Struggle to Slow Global Warming. Princeton: Princeton University Press, 2004.

Wapner, Paul. Environmental Activism and World Civic Politics. Albany: State University of New York Press, 1996.

Zelko, Frank. Make it a Greenpeace: The Rise of Countercultural Environmentalism. Oxford: Oxford University Press, 2013. 